\title{
Archaeological Investigation at the Marshall Powder Mill (41HS17), Confederate States of America 1863-1865, Harrison County, Texas: 1994 Season
}

Thomas E. Speir

Unknown

David H. Jurney

Follow this and additional works at: https://scholarworks.sfasu.edu/ita

Part of the American Material Culture Commons, Archaeological Anthropology Commons, Environmental Studies Commons, Other American Studies Commons, Other Arts and Humanities Commons, Other History of Art, Architecture, and Archaeology Commons, and the United States History Commons

Tell us how this article helped you.

This Article is brought to you for free and open access by the Center for Regional Heritage Research at SFA ScholarWorks. It has been accepted for inclusion in Index of Texas Archaeology: Open Access Gray Literature from the Lone Star State by an authorized editor of SFA ScholarWorks. For more information, please contact cdsscholarworks@sfasu.edu. 
Archaeological Investigation at the Marshall Powder Mill (41HS17), Confederate States of America 1863-1865, Harrison County, Texas: 1994 Season

\section{Creative Commons License}

(c) (1) (8)

This work is licensed under a Creative Commons Attribution-NonCommercial 4.0 International License 


\title{
ARCHAEOLOGICAL INVESTIGATIONS AT THE MARSHALL POWDER MILL (41HS17), CONFEDERATE STATES OF AMERICA 1863-1865, HARRISON COUNTY, TEXAS: 1994 SEASON
}

Thomas E. Speir and David H. Jurney

\begin{abstract}
The Northeast Texas Archeological Society, in conjunction with the East Texas, Dallas, and Tarrant County archeological societies, reinstated archaeological investigations at the Marshall Powder Mill (41HS17) in 1994 following several years of delicate negotiations with the landowner about the value of preserving this archaeological site. The Marshall Powder Mill manufactured gunpowder, small arms and cannon, and refurbished weaponry, and was one of several arsenals that served the Trans-Mississippi Department of the Confederate States of America from 1863 to 1865 . None have been thoroughly investigated archaeologically, however, thereby ignoring a major aspect of the Confederacy's war effort, and an important industrial enterprise.

Building foundations, earthworks, roads, and an artificial channel race remain essentially undisturbed within the Loop 390 corridor and the privately-owned portions of the site; the eastern one-third of the site has been destroyed by a modern lumber mill. Although the site is listed on the National Register of Historic Places, there is no concerted plan for preservation of this Civil War military-industrial complex.

Little historical documentation exists as to the number and types of buildings, their locations, or the activities that were conducted at the Marshall Powder Mill. The single map in the National Archives was captured by Federal troops in 1864, and only indicates a few of the buildings and none of the earthworks. Apparently the Confederates were concerned with security, and the commander, Major George D. Alexander, destroyed or removed all records prior to Federal occupation of the site in 1865. Therefore, the archaeological remains speak the clearest about the Marshall Powder Mill's buildings and their functions, and may be the only sure means of reconstructing the layout and design of the arsenal, as well
\end{abstract}


as ancillary fortifications, buildings, and structures around Marshall that date to the Civil War period.

\section{INTRODUCTION}

The Marshall Powder Mill manufactured gunpowder, small arms and cannon, and refurbished weaponry. It is one of several arsenals that served the Trans-Mississippi Department of the Confederate States of America, and was among the last in operation from 1864 to 1865 . None have been thoroughly investigated archaeologically, thereby ignoring a major aspect of the Confederacy's war effort and an important industrial enterprise.

The Northeast Texas Archeological Society (NETAS), in conjunction with the East Texas, Dallas, and Tarrant County archeological societies, conducted investigations at the Marshall Powder Mill (41HS17) Harrison County, Texas throughout 1994. The last professional archaeological investigations of the Marshall Powder Mill were

conducted in the southern one-third of the site by the Texas Highway Department in the early 1970s, when the Loop 390 by-pass was constructed on the northern outskirts of Marshall (Weir 1973; Luke 1978:137). Three building foundations (e.g., a large stone and brick building of unknown function, a blacksmith shop, and a possible sulphur distillery) and an artificial pond were investigated within the direct highway impact zone. Since then, the site has suffered extensive relic collecting, which has increased significantly with the use of metal detectors.

Members of the Northeast Texas Archeological Society persuaded some of the landowners to restrict such looting and to allow a detailed re-evaluation of the site. Building foundations, earthworks, roads, and an artificial channel race remain essentially undisturbed within the Loop 390 corridor (in fact, it appears that the building foundations were simply buried under fill) and the privately-owned portions of the site; the eastern one-third of the site was destroyed by a modern lumber mill, however. Although the site 
is listed on the National Register of Historic Places, there is no concerted plan in place that will insure the preservation of this important military-industrial complex.

The 1994 project was directed by David H. Jurney, Principal Investigator, and Thomas E. Speir, Project Director. It consisted of three field schools: a Southern Methodist University graduate seminar in high resolution rcmote sensing and surveying taught by Dr. James M. Adovasio (Mercyhurst College, Erie, Pennsylvania); field excavation, analysis, and conservation techniques taught by Brenda Whorton to the 7 th grade of the Dallas Episcopal School; and the NETAS/East Texas Archaeological Society Field School taught by David Jurney, assisted by Thomas Speir, Velicia Hubbard, and Mike Turner, which focused on: (I) vegetation control and removal, (II) remote sensing for building foundations in the northern portion of the site, (III) high resolution mapping, and (IV) limited excavations focused on a building interpreted to be a foundry. Approximately 150 participants and visitors visited the complex during the field schools.

Ancillary tasks included examination of the Marshall Powder Mill collections at the Texas Archeological Research Laboratory (TARL) in Austin (conducted by Mike Turner and Bo Nelson), an inventory of private collections in Northeast Texas (Tom Speir and Erwin Roemer); visiting the National Archives in Washington, D.C. (Jennifer Stabler); compilation of an archival file on Harrison County (Tom Speir); and interviews of descendants of Civil War participants (Tom Speir). In addition, a Civil War reenactment of a camp scene was performed by the late Larry Fant., then President of NETAS

Despite diligent research in the 1970 s and extensive modern searches, few additional archival sources were located. This significant site has little historical documentation as to the number and types of buildings, their locations, and the activities that were conducted there. The single map in the National Archives, for instance, was captured by Federal troops in 1864 , and furthermore it only indicates a few of the buildings and none of the earthworks. Apparently, the Confederates were concerned with 
security, and the commander, Major George D. Alexander, destroyed or removed all records prior to Federal occupation of the site in 1865. Therefore, the archaeological remains speak the clearest about the Marshall Arsenal's buildings and their functions, and may be the only sure means of reconstructing the layout and design of the arsenal, as well as the ancillary fortifications, buildings, and structures within and around Marshall.

This report points to the need to develop a plan to record and conserve morc Civil War era sites in Texas. There is no state-wide plan to inventory, assess, or protect such sites. Therefore, we view this report as an important step toward compilation of such an inventory and plan.

\section{ENVIRONMENTAL SETTING}

Harrison County (Figure 1) is located in the West Gulf Coastal Plain physiographic province. The parent material is interbedded sandstones and shales of the Reklaw and Weches formations. The Marshall Powder Mill is located in an area of shallow Cuthbert (clayey, mixed, thermic Typic Hapludults) gravelly fine sandy loam, soils with 5-15 percent slopes and deep Mooreville (fine-loamy, siliceous, acid, thermic Aeric Fluvaquents) and Manhache complex (fine-loamy, siliceous, acid, thermic Fluvaquentic Dystrochrepts) soils which are frequently flooded (Golden et al. 1994:120146). It is situated at the headwaters of Gray's Creek, which drains north into Caddo Lake. The elevation ranges from ca. $305-380 \mathrm{ft}$ amsl at the Powder Mill.

The climate in Harrison County is marked by hot summers dominated by Gulf air masses, with cool winters and occasional surges of Arctic air masses. Rainfall averages $119.13 \mathrm{~cm}$, uniformly distributed with a slight peak in spring. Temperatures on record include $110^{\circ} \mathrm{F}$ on 13 August 1962 and $0^{\circ} \mathrm{F}$ on 11 January 1982. Thunderstorms occur ca. 44 days a year, with occasional tornadoes and severe storms. The sun shines 75 percent of the time in summer and 55 percent of the time in winter (Golden 1994:3) 


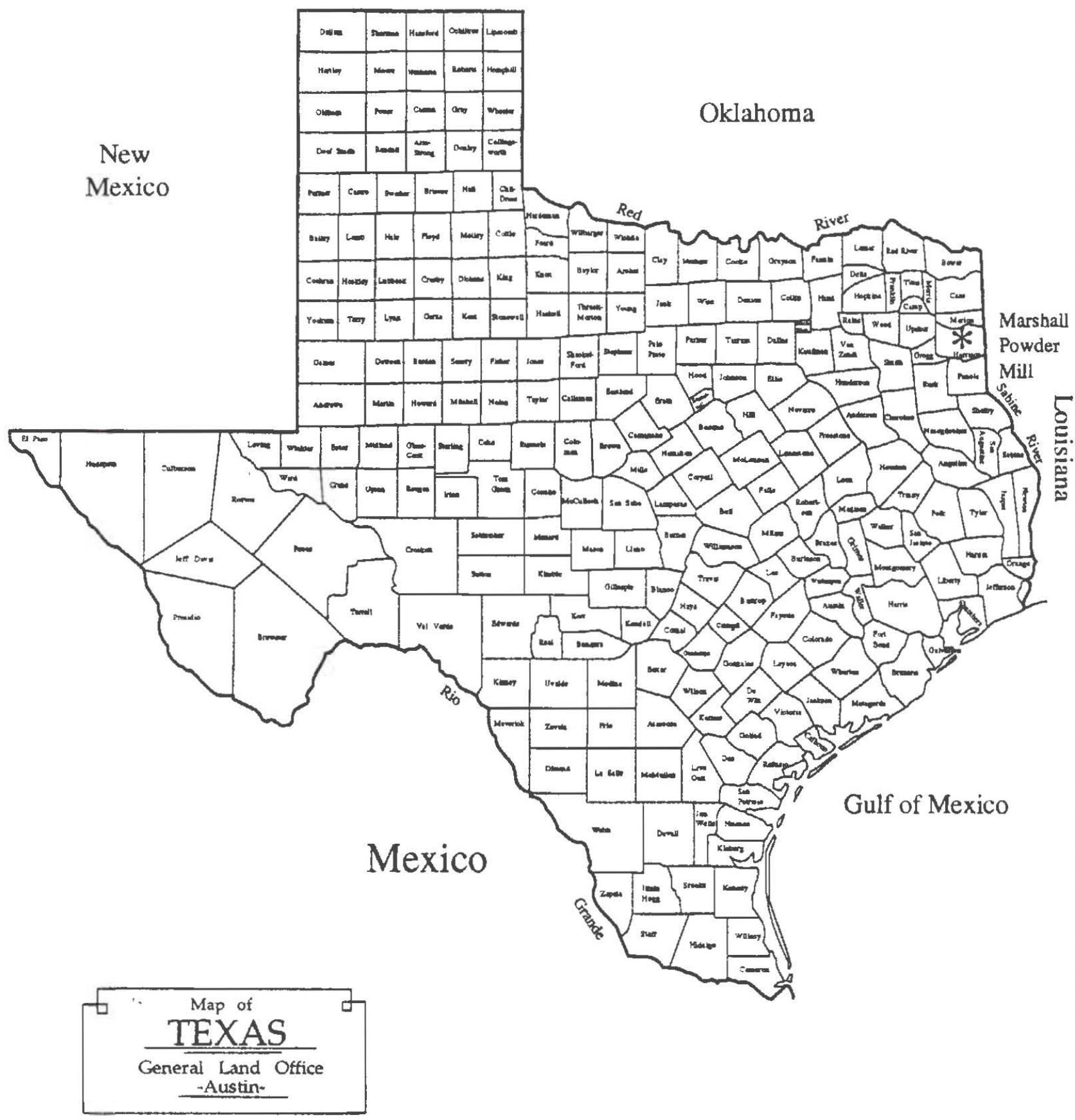

Figure 1. The location of the Marshall Powder Mill in Texas. 


\section{HISTORICAL BACKGROUND}

\section{The Trans-Mississippi Department Of The Confederacy}

One of the major objectives of the Union Army during the Civil War was to take possession of the Mississippi River and thus divide the Confederacy. To consolidate the Confederate chain of command west of the Mississippi, the Trans-Mississippi District and the Department of Texas were combined May 26, 1862, to form the TransMississippi Department. General E. Kirby Smith was appointed commander of the entire Trans-Mississippi Department (Parks 1954:251).

The fall of Vicksburg on July 4, 1863, achieved the Union's goal (Evans n.d.:105). On July 13th of that year, General Smith re-organized the wcstern states so they could be self-dependent (Luke 1978:4). A description of these events is found in Coulter's A History of the South:

The Confederacy was now cut into two parts. A year before the fall of Vicksburg, Governor Frank R. Lubbock of Texas believed that the TransMississippi region ought to be given a sort of autonomy within the Confederacy. In early 1863 the Trans-Mississippi Department was set up and placed under the command of General E. Kirby Smith, and after the fall of Vicksburg his powers both military and political were so greatly increased that he controlled this region almost as completely as (President Jefferson) Davis ran the Confederacy east of the Mississippi. He appointed officers and promoted them, provided for the exchange of prisoners of war, sent diplomatic agents to Mexico, controlled cotton exports, directed conscription, called together in council the governors of the three states that made up his domain, issued proclamations for thanksgiving and prayers; in fact, in the words of Davis, He has authority to execute the laws, and this is the only authority I have. Bureaus of the War, Treasury, and Post Office departments were set up. Indeed, this region was Kirby- 
Smithdom, with its twin capitals at Shreveport, Louisiana, and Marshall, Texas (Coulter 1950:358-359; emphasis in the original).

The need for ammunition and weapons was critical. An ordinance manufacturing post was established in Little Rock, Arkansas until threatened by Federal forces, when Smith ordered the removal of these works to Arkadelphia where another facility had been established (Albaugh 1958:34). On October 22, 1863, Smith's Chief of Ordinance and Artillery, Major Thomas G. Rhett, ordered those works, as well as those in Camden, Arkansas, moved south to Texas (Scott 1888:1141). Plans were made for the construction of new ordinance works in Shreveport, Louisiana, and Marshall and Tyler, Texas, among other smaller enterprises. Major Rhett rented land in Shreveport on June 16, 1863 for the construction of an arsenal. Captain F. P. Leavenworth was placed in command and already had machinery erected and a foundry established by the time the land lease was completed (Albaugh 1958:37).

A report made to the Confederate Congress on August 18,1863, stated that Texas had four gun factories making 800 arms a month, two powder mills, and a percussion cap factory. The gun factories were those of Billup and Hassell at Plentitude, Whitesearver and Campbell at Rusk, N. B. Tanner at Bastrop, and Short and Biscoe at Tyler (Military Papers, Texas State Archives, n.d.; Richard D. Stewart, personal communication to Thomas Speir). Powder Mills were established at Marshall and Waxahachie. Percussion Cap factories were established at Austin, Houston, and Fredericksburg. Arms were repaired at Houston, San Antonio, and Bonham. Cannon were cast at the state foundry at Austin and by E. B. Nichols at Galveston.

The Waxahachie Mill was established in 1862 or 1863, but blew up (attributed to both an accidental spark and a northern spy) on April 30, 1863. Three men, William Rowen, Joshua G. Phillips, and David Nance (born in Cass County, Illinois on February 2, 1843, and a DeSoto, Texas rcsident by 1852), who were originally assigned to Cloth 
Mills at Lancaster, and Stephen Mulkey, were severely burncd; Rowen and Phillips were fatally burned:

Mr. Rowen was the owner of the mill and the State of Texas furnished him all the sulphur, saltpeter, etc. and the powder was manufactured on the halves. Motive power was 10 mules working in a tread mill, it had 10 marters (sic) each large enough to work 25 pounds. It also had a stone press capable of a pressure of about $1200 \mathrm{lb} / \mathrm{sq}$. inch with a capacity of 25 pounds at one charge. There was a crushing machine, a shaving machine for making powder-powder into grains from the hard cakes and a glazing cylinder (The Waxahachie Daily Light 3 April 1936, Interview of Ms. Mollie Phillips).

Therefore, the above-mentioned report to the Confederate Congress was somewhat erroneous; the Waxahachie Mill had already blown up. Undoubtedly, Marshall played the dominant role in the production of gunpowder for the Trans-Mississippi Confederacy. The ingenious use of water to power the mill, in contrast to the Waxahachic mill, and additional manufacturing activities, greatly enhanced the production of powder and arms at Marshall.

\section{MARSHALL, TEXAS}

General E. K. Smith established the headquarters of the Trans-Mississippi Department in Shreveport; however, a yellow fever epidemic there prompted him to move most of his operations to Marshall (Albaugh 1958:37). This included the removal of his own family from Shreveport to the home of Senator Louis T. Wigfall in Marshall (Parks 1954:328). The Quartermaster Bureau, under the command of Lieutenant Colonel L. W. O'Bannon was also emplaced at Marshall (General Orders 33, May 30, 1864; Nichols 1964:5). Other Bureaus established there included Conscription, Ordinance, Subsistence, and Medical. In actuality, Chief of Ordinance Bureau, Brigadier General 
Huger, whose headquarters were in Shreveport, Louisiana, had already moved his personal headquarters to Marshall by January of 1864 (Roney 1962:56), and Henry W. Allen, Governor of Louisiana, had moved his capital to Shreveport (Coulter 1950:399).

Smith's Chief of Ordinance Bureau was Major Benjamin Huger. His principal duties included receiving returned weapons, examination and correction of them, and forwarding them to Richmond. He was also responsible for the distribution of funds. These tasks differ from Smith's Chief of Ordinance on his staff, Major Rhett, who approved requisitions for arms and ordinance, controlled locations of foundries, and contracted for the manufacturing of arms and ammunition.

Marshall also had an agent for the Clothing Department, was home for the Missouri Government in exile, and was a destination for refugees from the eastern states. This may have been due to the availability of excellent rail and stage service in Marshall, as well as a courier and mail service (Roney 1962:56). A Confederate hat factory and a hide tanning facility also operated in Marshall during the war.

By 1857 , western rail service terminated in Tyler and extending east all the way to Vicksburg. Records indicate that on September 11, 1862 the line of the Vicksburg, Shreveport, and Texas Railway Company between Waskom and Shreveport was leased by Southern Pacific to extend their line for 43 miles. During the Civil War, General Magruder had the track taken up between Marshall and Swanson's Landing on nearby Caddo Lake, and relaid it between Marshall and Waskom, on the Louisiana border (Texas and Pacific 1947).

Concern over a possible invasion by the Union army was centered initially on the Gulf Coast, where major cities and ports were fortified and manned by troops. General Smith believed that the only possibly successful line of attack on his department would be in the Red River Valley. Accordingly, fortification of Shreveport and Marshall was undertaken. These defenses included a division of troops under the command of Major 
General Churchill. Additionally, the following artillery units were still stationed in Marshall at the end of the war:

Reserve Artillery, Major M. V. McMahan, Commanding

2nd Arkansas Battery, Capt. W. Hart (No Guns)

3rd Arkansas Battery, Capt. J. G. Marshall (No Guns)

10th Texas Battery, Capt. H. C. Hynson (Armament unknown)

Unattached Units:

5th Arkansas Battery, Capt. C. C. Scott

2 Twelve-pounder Field Howitzers

2 Six-pounder Guns

4th Louisiana Battery, Capt. A. J. Cameron

1 Twelve-pounder Field Howitzer

3 Six-pounder Guns (Lambert 1992)

There are other surviving records of specific individuals stationed at Marshall, including: Issac A. Ward, Private, Peguees Company, Waterhouse Regiment, Walker's Division; J. H. Kennedy, Company A, First Texas, Hood's Brigade, Stonewall Jackson's Division, Longstreet's Corps, Army of Northern Virginia (Chief of Iron Department under Gen. Smith, then assigned to powder works at Marshall); and Wm. M. Hogsett, Private, Company K, Nineteenth Texas Infantry, Scurry's Brigade, Walker's Division.

Union officers realized that no amount of damage inflicted upon their own troops could compensate the Confederacy for the loss of these facilities (Parks 1954:328, 366, 412). A Union army under General Banks invaded the region in 1864. Although the campaign was directed in part towards Marshall (Weir 1973:2), the ultimate goal was the heartland of Texas (Evans n.d.:133). The fighting never got closer to Marshall than the Battle of Mansfield, Louisiana, on April 8, 1864, which was a Confederate victory.

At the conclusion of the war east of the Mississippi, General Smith still had an army of 30,000 men "which some Confederates hoped might have been the nucleus of a 
never-dying Confederacy to be transferred west of the river" (Coulter 1950:359). Jefferson Davis attempted to flee to Texas, and felt "it may be that our enemy will prefer to banish me. Or it may be that a devoted band of cavalry will cling to me, and that I can force my way across the Mississippi, and if nothing can be done there which it will be proper to do, then I can go to Mexico and have the world from which to choose a location " (Coulter 1950:563). On May 13, 1865, General Smith convened a meeting of the Trans-Mississippi governors and their representatives in Marshall to discuss their political status (Coulter 1950:566), three days after the capture of Jefferson Davis by Union cavalry. General Smith waited in vain for Davis to arrive until May 26th, when he surrendered his army; a month after Lee's surrender at Appomattox (Coulter 1950:563).

\section{THE MARSHALL POWDER MILL}

Prior to Confederate occupation, the land consisted of portions of three land grants, the Peter Whetstone (Shelby 1st Class, A-756, patented August 7, 1845: 4,428.4 acres) Survey, the John M. Clifton (Shelby Bounty, A-184, patented December 13, 1848 : 1,280 acres) Survey, and the James A, Chaffin (Harrison Ist Class, patented December 18, 1848) Survey. The undated (ca. 1864) map (Figure 2) indicates that the Chaffin Survey consisted of fields associated with the extensive farm complex of Judge Mills, who lived to the north. Apparently Mills also transferred title to the Confederacy. After the war, the title is confusing, until the land is tied into the Nancy Lambert Estate (Harrison County Deed Book 395:505), which was subdivided in 1990.

Command of the Marshall Powder Mill was assigned to Major George D. Alexander, a seasoned veteran of the Civil War. In 1861, he had organized a company in Arkansas and then fought with Stonewall Jackson in Virginia. In January 1862 he lost his left arm in battle. By March he was released from convalescence in Winchester and was on recruiting duty for the next two months. At the end of 1862, Captain Alexander 


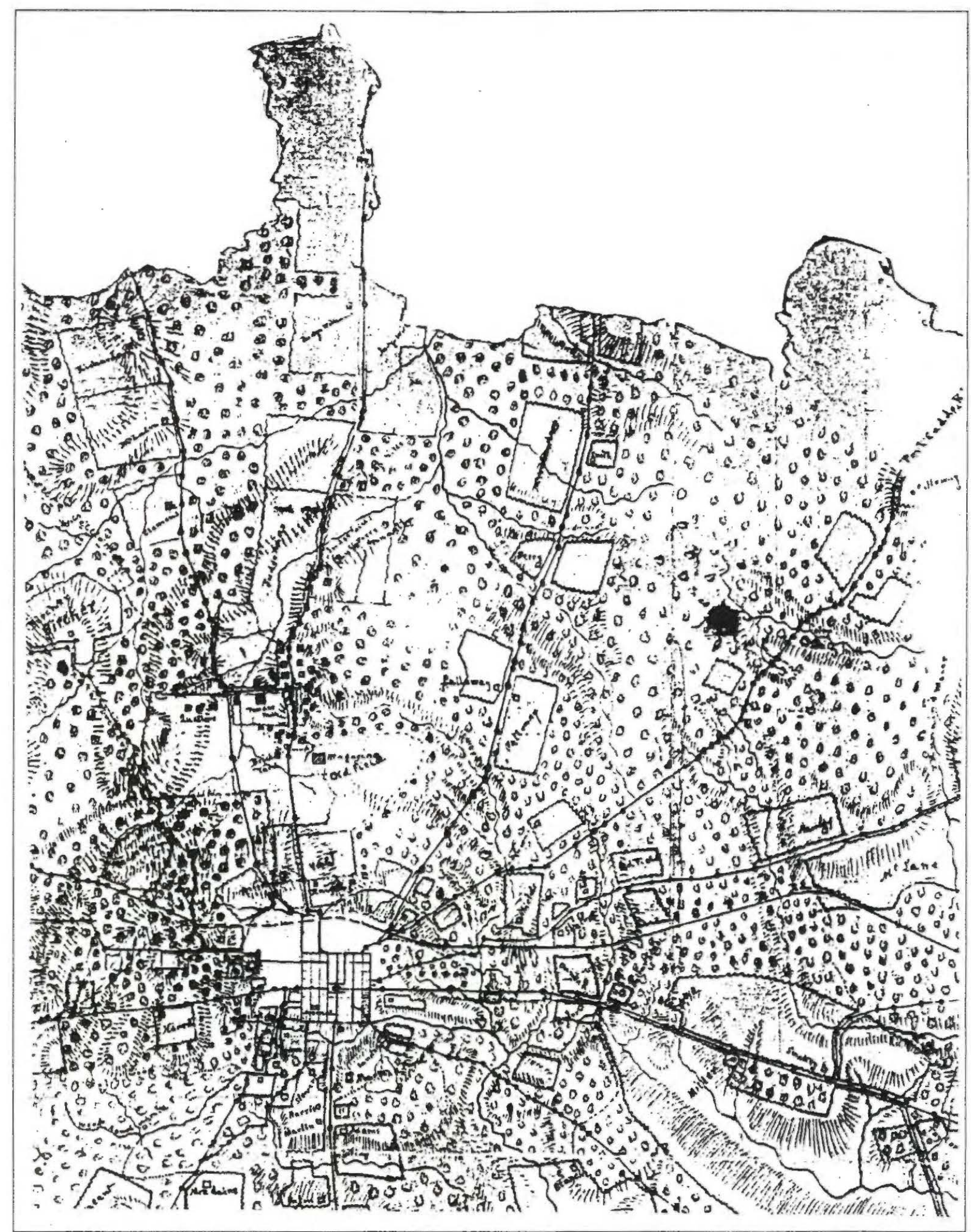

Figure 2. An Undated Confederate Map of "The Environs of Marshall Texas," captured by Federal troops (National Archives, Record Group 77, Map Z 52-5). The large dark splotch is one of several that suggest blood splatter. 
was in charge of the ordinance works in Camden, Arkansas that was principally involved with repair work.

The only remaining records specific to the Marshall Powder Mill, begin with a letter from Major Thomas H. Rhett, Smith's Ordinance staff officer to J. P. Johnson, Assistant Adjutant and Inspector General, on October 22, 1863, in which Rhett mentions: ...all these workshops and establishments have been removed to places of safety: the machinery, tools, stores, and men from Little Rock Arsenal to Tyler, Texas; the machinery, tools, stores, and men from Arkadelphia to Marshall, Texas; and the machinery, tools, stores, and men from Camden to Shreveport, Louisiana...At Marshall, Texas I am having buildings crected for manufacture of small-arms, smiths' and carpenters' shop, powder-mill and magazine, and am concentrating at that point large supplies of heavy material, such as saltpeter, sulphur, lead, and iron; and I intend it to be a depot for supplies arriving from Mexico (Scott $1888: 1141)$.

Even with the availability of some equipment and machinery from Arkadelphia, Alexander had the difficulties of designing buildings and drafting a construction work force. A certain percentage of this force was undoubtedly slave labor from the Shreveport Slave Bureau. Importation of goods across the Rio Grande had been blocked by either federal or French troops by October 1863 (Parks 1954:343). Alexander was then forced to rely on the available resources of the Trans-Mississippi Department. One advantage he enjoyed was his ability to commandeer the best blacksmiths, machinists, and gunsmiths before their assignment to other ordinance works, such as the one in Tyler. Alexander then could manufacture tools for construction purposes as needed.

As ordinance works had begun in Shreveport by June 16, 1863, and in Tyler by March 4, 1864, it is likely that work at the Marshall Powder Mill had also begun within this period. A letter from Huger to Johnson in January I 864 indicates production at the 
powder works would not begin for some time. The records from the Ordinance Works, Tyler consists of a "Day Book" whose records begin on Friday, March 4, 1864 and gives other clues to activities that occurred at Marshall. Other relevant records include the July 11, 1864 letter from Lt. Colonel G. H. Hill, Comdg., Tyler Ordinance Works, to Captain S. C. Faulkner, Commander of the Marshall Ordinance Depot under the jurisdiction of the Arsenal. The significance of this letter is a reference to nitric acid that was required for the supply of fulminate of mereury for percussion-caps. More direct evidence for the Marshall arsenal included a letter from Charles D. Curtman, Office Ordinance Laboratory, Marshall, to General Huger, dated July 29, 1864 which discusses the analysis and quality of a coal sample (the source of this sample is not mentioned) and the usefulness of this material in blacksmith forges, foundries, puddling furnaces, and bloomery.

The undated map (ca. 1864), captured by the Union Army, depicts the Marshall Powder Mill and the Marshall vicinity. Large dark splotches (one is shown in Figure 2), exhibiting a splatter pattern on this map suggest blood; and the wear to the upper edges also confirm a violent history for the document. Since not all known features are shown on this map, it is believed to date to early 1864 . One side of this map shows the townsite of Marshall, with an arsenal downtown, an Ordinance Laboratory on the southwestern border of the city, and a troop camp by a spring on the Elysian Fields Road. On the reverse, labeled "Environs of Marshall Texas" and "49 Shreveport," is a circular "artillery" map showing cleared fields, farms, roads, streams and what appears to be a complex of buildings in the vicinity of the "Powder Mill." West of the Mill are shown three "quarters." A building is shown immediately north of the Mill, adjacent to the stream; and at least six buildings are shown on the ridge east of the Mill. A "brick yard," at least three buildings, and a "magazine" are shown southeast of the Mill. Dots shown on all roads are apparently picket posts (Gregory et al. 1984:45-47). Certain features, such as the direction of the stream by the Mill, appear to have been altered, possibly to 
deceive the enemy. Other constructions not shown on this map include the channel race by the mill, gun emplacements to the west and to the east of the stream, wells, earth embankments and a reservoir complex to the south, cotton bale barriers to the east, and a large " $\mathrm{G}$ " shaped fortification on a nearby hilltop that overlooked the facility.

In addition to this information, three mills, set near springs on the headwaters of streams, are shown south of Marshall. The camp, arsenal, and ordinance laboratory are also shown and labeled. Residents and owners of farms are indicated, and vacant land is also noted. Arrays of dots, suggesting defensive alignmonts of picket posts, are shown at strategic places across this map.

Although General R. E. Lee surrendered to General Grant on April 9, 1865, General Smith did not surrender until May 26, 1865. A letter dated May 28, 1865 from Flanagin to A. H. Garland indicates "the command at Marshall is furloughed." However, an editorial on June 2, 1865 in the Texas Republican reveals that, although the powder in the mill itself had been carried off, there rcmained "at least sixty thousand pounds of cannon powder in the Magazine, besides a quantity of fixed ammunition." The proximity of the Magazine to the Powder Mill can be seen in the undated map. This same editorial also reveals that Major Alexander, builder and Commanding Officer of the Marshall Powder Mill, was still in the area, providing a demonstration to the local population of the dangerous nature of the remaining powder which citizens of the town were apparently looting. The final paragraph indicated that guarding of the Magazine was being terminated.

Federal troops arrived in the area later in June. They began dismantling the mill in August. On September 1, 1865 the Texas Republican reported an accidental explosion of the mill caused by Union troops striking a spark with a hammer during the dismantling of the powder mill itself. Surprisingly, there are no Federal maps or records yet located that provide the layout and structure of the Marshall Powder Mill complex. 
This concludes the bulk of the known records of the history of the Marshall Powder Mill. Local verbal tradition indicates that after Federal demolition, citizens from the town plundered the site for building materials, particularly brick. The 1973 study indicates that some walls, such as that for the forges in the blacksmith shop, had been toppled for salvageable brick (Luke 1978:35).

In the decades that followed, the area was used as a picnic area, a campsite, and a dumping ground, supported by evidence found in a ravine filled with refuse dating from the early twentieth century. Finally, a pasture was made after clearing west of the creek with a bulldozer, which may have been necessary to fill a large fortification ditch in this area.

\section{HISTORY OF INVESTIGATIONS}

The Marshall Powder Mill was initially recorded with the State of Texas by S. Alan Skinner of Southern Methodist University in 1971. Interviews and investigations at this time indicated that the complex may have contained over 40 buildings (Whaley 1919:17; Luke 1978:17). Foundations of at least 12 buildings, earthworks, and historically reported features (i.e., a cotton bale barricade) distributed over ca. 53.16 hectares (131.31 acres) were mapped in 1971 within and adjacent to the Texas Department of Highway's (now the Texas Department of Transportation) planning corridors for Loop 390 (Weir 1973). The original corridor was shifted to the south, avoiding the ca. 6.0 hectares ( 14.9 acres) central portion of the site. Salvage excavations in the Loop 390 corridor (Figure 3) yielded evidence for a blacksmith shop, a possible machine shop, and a pond (Luke 1978). There have been no systematic archacological investigations of any remaining portions of the site. It has been damaged to various extents by construction of a sawmill, a gas pipeline, and relic hunters using metal detectors. 


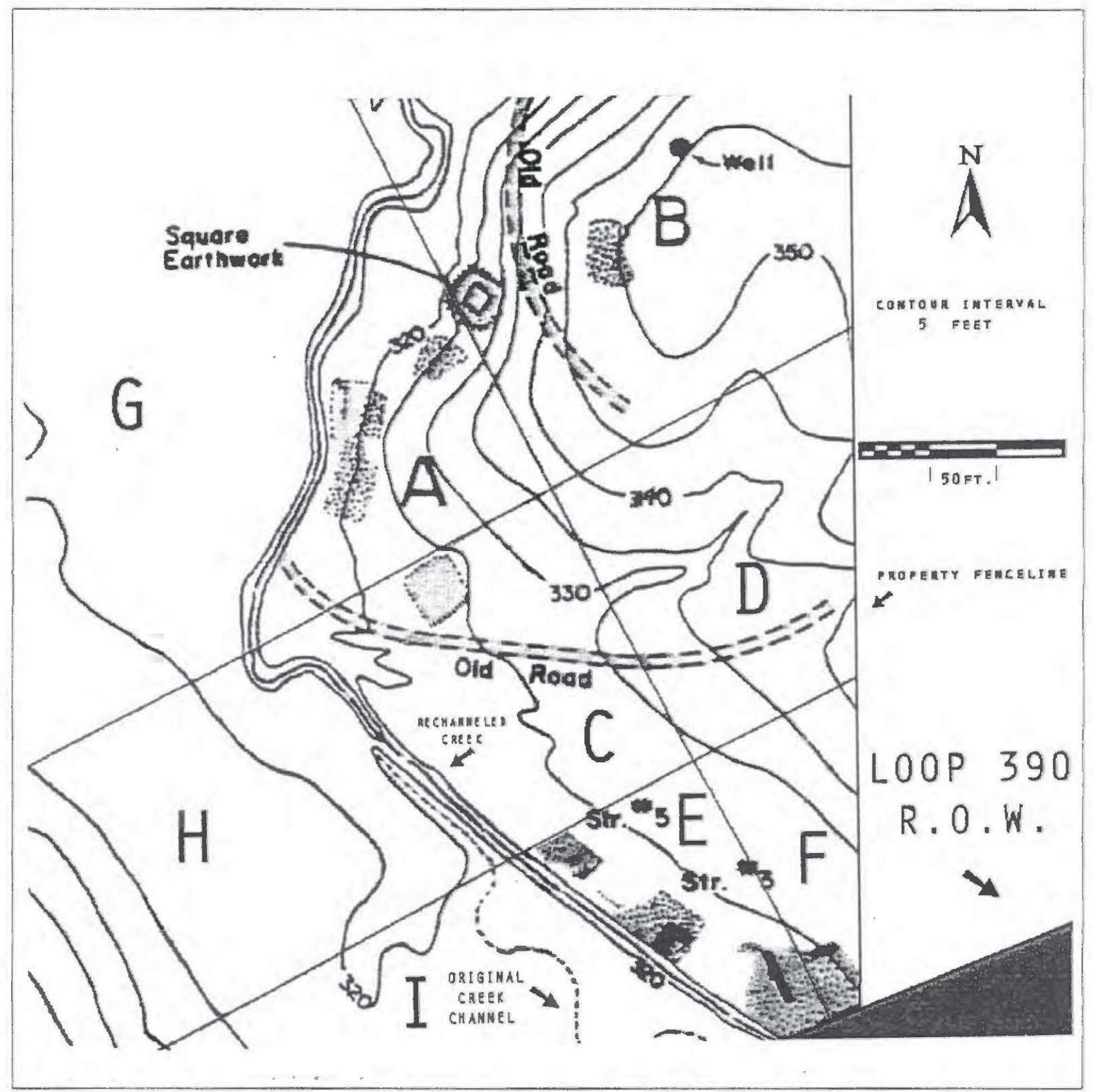

Figure 3. Analytical Divisions of the Marshall Powder Mill (after Weir 1973). 
Based on the arcal designations established by Weir (1973), the core of the site was divided into six principal study areas (see Figure 3) to facilitate renewed archaeological investigations and discussion. A baseline was arbitrarily drawn parallel to the Loop 390 right-of-way (ROW), 122 m (400 feet) northwest of the north ROW fence; this served as the southernmost boundary of Study Areas A and B. The division of Study Areas A and B is based on the location of the square earthwork mapped in 1971 (Weir 1973). A second baseline parallel to the first was drawn $61 \mathrm{~m}(200 \mathrm{ft})$ from the north ROW, defining Study Areas C, D, E, and F. Study Areas C and D have suffered extensive erosion and trash dumping activities between ca. 1930-1950, while Study Areas E and F contain features (e.g., Structures 3, 4, and 5) mapped in 1971 (Weir 1973:22) and partially excavated in 1973-1974 (Luke 1978).

\section{PRESERVATION NEEDS}

Ownership of the Marshall Powder Mill has passed through many hands, and is split among several private and public entities today. As noted above, a lumber mill has destroyed the eastern portion of the site, and Loop 390 bisects the complex, with the northern (Good News Christian Church, O. C. Phillips, and Ronnie Snider) and southern (portions owned by East Texas Baptist University?) portions of the site still largely intact. Close examination of the foundation of Structure 71-4 (Weir 1973), and the landscaping associated with the Loop 390 corridor, indicates that the excavated and unexcavated portions underlying the Texas Department of Transportation ROW remain intact as well. Development, including pond construction, has affected building foundations and earthworks along the western margin, while continued development by the Good News Baptist Church threatens a gun emplacement and possible subsurface features.

In January 1993, James E. Bruseth and Timothy K. Perttula from the Department of Antiquities Protection at the Texas Historical Commission (DAP-THC) were given a tour of the site by Thomas Speir (NETAS), and then provided recommendations for 
future preservation/archaeological action. Their visit was followed up in January 1994 by Mark Denton, a staff historic archeologist for the DAP-THC. He noted impacts to the site by decades of collectors, private construction on neighboring properties, and environmental damage. He recommended immcdiate action to stabilize the site. His recommendations included cleaning of foliage and leaf mold in preparation for mapping the site. Preparation for this work revealed extensive environmental damage to at least one major feature.

A site preservation program was proposed to deal with this and any future problems that might impact this important site. The work was implemented February 12 , 1994 by members of NETAS, the Dallas Archeological Society (DAS), and local brick and material culture experts. Due to conflicting schedules, Mr. Denton arranged for David Jurney (then of the Archaeology Research Program, Mercyhurst Archaeological Institute) to attend. David Jurney was requested by the NETAS to serve as the Principal Investigator during the conduct of the following investigations.

A 14.9 acre (6.0 hectares) central portion of the site owned by Mr. Olan Phillips, of Marshall, contains the remarkably undisturbed remains of several buildings and earthworks. However, the foundations of a large rectangular building, labeled Building A-1-1994 (Figure 4), have been severcly undercut by channel erosion and beaver tunneling activities. This area was the focus of vegetation clearance, mapping, remote sensing, and excavation to determine if building functions could be identified and thus help to elucidate the history of the Marshall Powder Mill complex.

\section{RESEARCH DESIGN}

Previous archaeological evaluations, although appropriate at the time, have operated in a piecemeal manner and neglected the evaluation of the Marshall Powder Mill complex as a wholc, particularly in relation to its role in the greater theater of war. The first priority was to accurately document the surface manifestations at the site and halt 


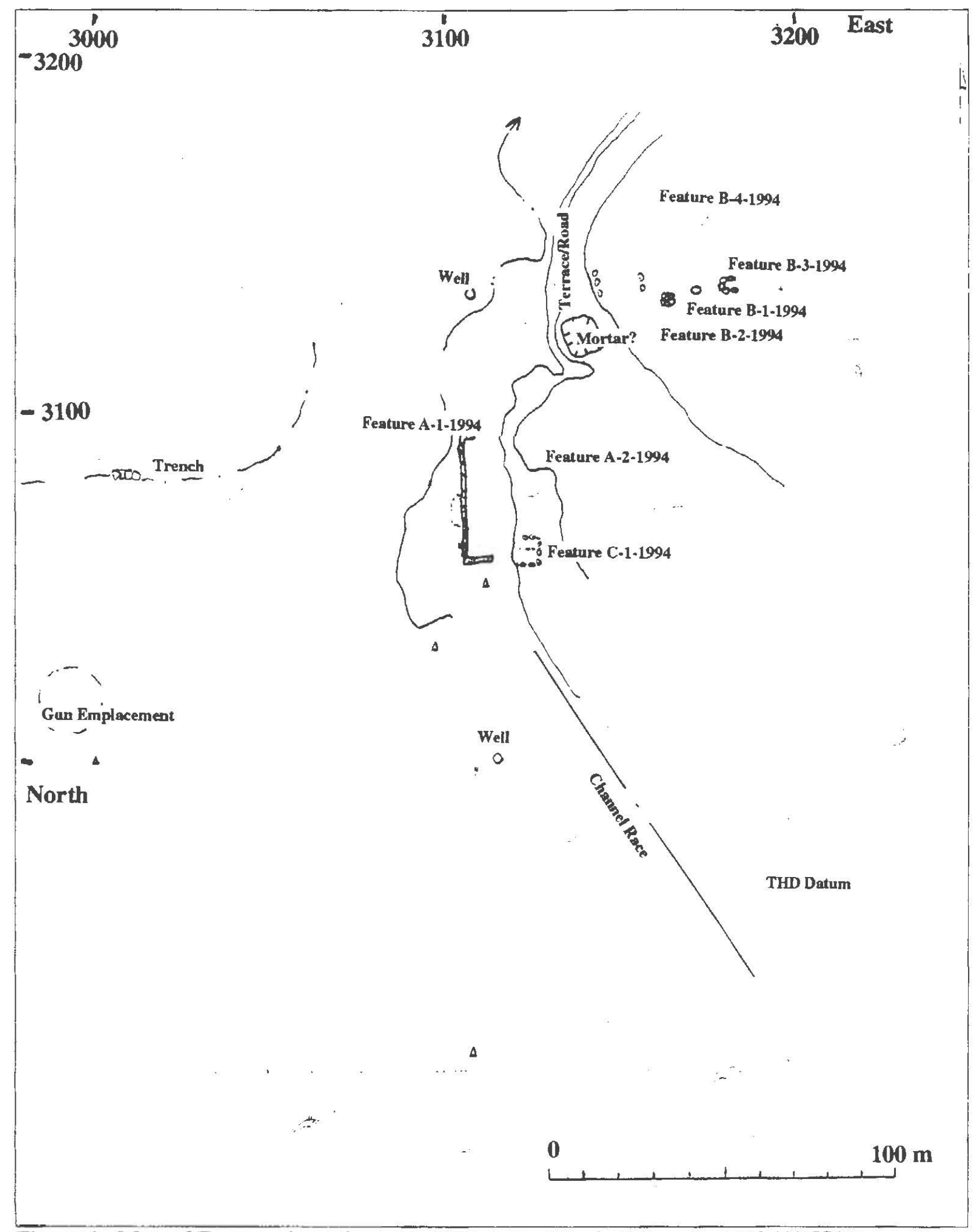

Figure 4. Map of Features investigated in 1994 at the Marshall Powder Mill (41HS17). 
natural impacts to extant features. Access was limited to the 14.9 acre parcel and a 24 acre northern parcel owned by Mr. Olan Phillips, and portions of adjacent parcels that he has leased.

The research design for the Marshall Powder Mill and Arsenal focused on the documentation of surface manifestations and the mapping of subsurface anomalies that may be used to identify the function of buildings and structures. Non-invasive remote sensing techniques were employed to trace subsurficial features. Physical hand-controlled excavations were limited to areas already exposed by natural erosion or impacts.

This research design specified 11 tasks, planned to accommodate up to five groups of three people each (one experienced with two novices) operating across the site. To facilitate site discussion, a zonation (see Figure 3) was employed that generally parallels the English grid system and maps provided by the Highway Department (Luke 1978). The grid that we have established is aligned with cardinal directions and is recorded in meters (i.e., eastingRnorthing).

Area A consists of the portion of the site west of the "square earthwork" and east of the stream channel. One large building (mapped as two buildings in 1973) commands this area. It is labeled Feature A-1-1994, and consisted of a two-course rock footer that was once topped by a one or two story hand-made brick superstructure (Eugene Foster, personal communication to David Jurney, 1994). The rock foundation is not continuous, and is open on the east, suggesting an open or framed exterior wall. A series of brick and rock alignments and depressions along the hill side adjacent to Feature A-1-1994 may have been attached or associated with the functioning of the larger building. One of these, identified by metal scans as a possible smelter (A-2-1994), was exposed.

Area B consists of the portion of the site east of the "square earthwork" and east of the stream channel. A well (B-1-1994), a north-trending "old road," and an apparent building were mapped here in 1973. Close examination of this area reveals two possible buildings adjacent to the well (B-2-1994 and B-3-1994), which has been impacted by a 
Journal of Northeast Texas Archaeology, No. 8 (1996)

gas pipeline. In addition, a serics of terraces and buildings are indicated by surficial evidencc and remote sensing in this area. Melal scans north of the pipeline indicated another arca (B-4-1994) which suggests a building location.

Area $\mathrm{C}$ is the portion of the site from the east-trending "old road" to the Loop 390 right-of-way (ROW) and east of the rechanneled creek. It encompasscs three possible buildings (e.g., Structure 5, 3, and 4, listed in order from northwest to southeast, that were mapped in 1973). Actually the "rcchanncled creek" is a constructed channel race for the emplacement of undershot, or iron box-contained horizontal water-powered turbines (Jack Jackson, Fort Hood archaeologist, personal communication to David Jurney, 1995), associated with Structures 3-5 and those excavated by Luke (1978) farther to the south. Limited excavations were performed by the Texas Highway Department at these building loci. The Powder Mill itself apparently sat just south of the current Loop 390 ROW. The northern boundary of Area $\mathrm{C}$ abuts Area A, where another possible building or depression (C-1-1994) was exposed.

Area D is the portion of the site, labeled Excavation Area III in 1973, which has suffered extcnsive erosion. It has also been used for dumping during the carly twentieth century, possibly from tenant houses that were located somewherc uphill, in today's lumber mill owned by Ronnie Snider. The east-trending "old road" dominates this area. If it was used as a road, erosion has eliminated the evidence for this.

Area $E$ is the portion of the site west of the channel race. Surficial evidence suggests that the natural stream channel is located here, before it was relocated into the channel race. A circular depression may represent the location of a seep well. A large mound of rock and hand-made brick is located in this area, just west across the stream from "Structure 3."

Area $\mathrm{F}$ is a small section of the site along the Loop 390 ROW. It is east of 1971 Structure 3, and the area is thickly overgrown. 
Area $\mathrm{G}$ is the portion of the site west of the stream and north of the apparent location of a break in the channel race. This area is subject to flooding, and served as our stream crossing onto the excavation area and Feature A-1-1994. A gun emplacement is located on the hilltop facing north toward a large ridge spur (identified as an "earthworks" in Weir [1973]) in the treeline. In the field at the bottom of the hill is a rock feature within the current field road, and an apparent east-west trending entrenchment that defends the gun emplacement. Remote sensing indicates masses of metal within this trench, and scattcred metal to the north, suggestive of gun fire.

Task 1. The established grid system was used to map and record all surficial features in Areas A-D, inclusive. Crews worked with the transit in Area $\mathrm{A}$, and flagged potential features for surficial denudation, not


subsurface buildings were present.

Task 2. The series of $1 \times 1 \mathrm{~m}$ excavation units begun by the Episcopal School in April were reopened in October, and excavation continued until the nature of the fill of Feature A-1-1994 was defined. Task 2 was to define the nature of the fill of Feature A-1-1994, anticipated to be ca. $1 \mathrm{~m}$ below surface. An exploratory sondage to the floor of the basement of Feature A-1-1994 was to be performed only if the remaining tasks were completed. The unit was to be backfilled and the foundation stabilized.

Task 3. A $2 \times 2 \mathrm{~m}$ block was excavated at the place shown as a junction between two buildings on the 1973 map. This area appears to be a projection of Feature A-1-1994, and remote sensing indicated the presence of an iron girder and large amounts of molten iron within the fill of the building's basement in the locus. 
Journal of Northeast Texas Archaeology, No. 8 (1996)

Task 4. A profile was carefully cut within the location of an armadillo burrow at the eastern end of the excavation trench through Feature A-11994. The profile revealed the soil stratigraphy of the hill slope, but no buried foundation wall or construction trench.

Task 5. A depression, Feature A-2-1994, located upslope from Feature A1-1995 was tentatively identified as a smelter on the basis of remote sensing. Two $1 \times 1 \mathrm{~m}$ excavation unit were emplaced to provide subsurface characterization of the featurc.

Task 6. The wcll, located within a pipeline ROW, was investigated by the emplacement of a $2 \times 2$ m block to examine the construction of the eastern half of the feature (Feature B-1-1994). Three adjacent rock mounds received surficial denudation and mapping, but no excavations.

Task 7. (not completed) Metal detecting shifted focus to the southern portion of the pasture, Area E. This was to be conducted around the mound apparently associated with "Structure 3" (Feature E-1-1994) and along the supposed original stream channel.

Task 8. (not completed) A $1 \times 1 \mathrm{~m}$ excavation unit was to be emplaced by the next available crew to provide subsurface characterization of Feature E-1-1994.

Task 9. (not completed) A soil profile characterization of the natural floodplain alluvial deposits was to be attempted with the aid of a bucket auger. This task was to aid in the overall characterization of the site's stratigraphy.

\section{DISCUSSION}

Due to weather and logistical considerations, not all of the objectives of the Research Design could be addressed. Continuous rains prevented excavation in the 
Feature B-1-1994 arca, and reduced the extent of excavations at Features A-1-1994 and A-2-1994. Additional features (B-2-1994, B-3-1994, and C-1-1994) werc cxposed and mappcd by surface exposure, probing, metal detecting, and remote sensing using Inductive Conductivity (radio waves). Only those features which received excavation or controlled exposure will be discussed in the body of this report.

\section{RESULTS OF INVESTIGATIONS}

The archaeological investigations consisted of the emplacement of grid units over six features (i.e., A-1-1994, A-2-1994, B-1-1994, B-2-1994, B-3-1994, and C-1-1994) and the point-plotting of trowel tests associated with a metal scan of a possible building (Feature B-4-1994) or watch post north of the Pipeline ROW. In addition, new features and the structures identified by the Texas Highway Department (Table 1) were mapped and given grid unit designations that encompassed the surficial evidence for them. Critical points of reference include the southwestern property corner $(3066.99303 R 2900.23758)$ for the 19.9 acre parcel owned by O. C. Phillips and an iron rebar (3192.10680R2959.67894) left in a balk of the Texas Highway Department excavations. Brass (3123R3079, 3123R3091) and iron spike (3113R3072, 3113R3053, 3123R3071) datums were left in baselines, and iron spike datums at random points (3184.33262R2940.97202, 3110.43014R2999.39779, and 2980.16296R3134.76019) across the property; a particular effort was taken to recess all datums below the modern grade.

\section{Stratigraphy}

Four, natural, archaeological, or soil strata were defined at the Marshall Powder Mill. There was no attempt to correlate the stratigraphic sequence with the intricate stratigraphy of the Texas Highway Department excavations (Weir 1973; Luke 1978). The strata are given field designations in order of their discovery. These are then arranged in chronological order from oldest (lowest) to youngest (uppermost). 


\section{TABLE 1}

Listing Of Features (Areas A, B, C, D, E, and G) And 1994 Excavation Units At The Marshall Powder Mill

\begin{tabular}{|c|c|c|c|}
\hline Feature & $\begin{array}{l}\text { Provenience } \\
\text { E/N }\end{array}$ & Levels & Stratum \\
\hline $\begin{array}{l}\text { Pier } \\
\text { S Wall }\end{array}$ & $\begin{array}{l}\text { 3107R3090 } \\
\text { 3109R3090 } \\
\text { 3115R3090 } \\
\text { 3113R3084 } \\
\text { 3106R3068 } \\
\text { 3107R3068 } \\
\text { 3105-15R3056 }\end{array}$ & $\begin{array}{l}1,2,3,4,5,6 \\
1,2,3 \\
1,2,3 \\
1,2,3,4,5 \\
1,2^{*}, 3^{*}, 4 \\
1,2,3,4,5 \\
1\end{array}$ & $\begin{array}{l}\text { F3 (St.4), F4 (St.3), F6 (St.1) } \\
\text { F3 (St.4), F4 (St.3) } \\
\text { F3 (St.4), F4 (St.3),F6 (St.1) } \\
\text { F3 (St.4), F4 (St.3) } \\
\text { F3 (St.4), F5 (St.3) } \\
\text { F3 (St.4), F5 (St.3) } \\
\text { F3 (St.4), F4 (St.3) }\end{array}$ \\
\hline A-2-1994 & $\begin{array}{l}\text { 3080R3122 } \\
\text { 3080R3123 }\end{array}$ & $\begin{array}{l}1,2 \\
1,2,3,4\end{array}$ & - \\
\hline B-1-1994 & 3171-73R3133-35 & - & - \\
\hline B-2-1994 & $3163 R 3135$ & - & - \\
\hline B-3-1994 & $3181.4 \mathrm{R} 3135$ & - & - \\
\hline B-4-1994 & $\begin{array}{l}\text { 3177R3138.5 } \\
\text { 3175.5R3141.9 } \\
\text { 3173R3145 } \\
\text { 3169.5R3148 } \\
\text { 3173.3R3149.5 } \\
\text { 3173.5R3151 } \\
\text { 3183.8R3149 } \\
\text { 3186R3151 } \\
\text { 3184.2R3152.9 } \\
\text { 3184R3168 } \\
\text { 3187.5R3153.2 } \\
\text { 3193R3153.2 } \\
\text { 3187R3157 } \\
\text { 3187R3160 }\end{array}$ & $\begin{array}{l}1,2 \\
1,2 \\
1,2 \\
1,2 \\
1,2 \\
1,2 \\
1,2 \\
1,2 \\
1,2 \\
1,2 \\
1,2 \\
1,2 \\
1,2 \\
1,2\end{array}$ & $\begin{array}{l}\text { F3 (St.4), F4 (St.3),F6 (St.1) } \\
\text { F3 (St.4), F4 (St.3),F6 (St.1) } \\
\text { F3 (St.4), F4 (St.3),F6 (St.1) } \\
\text { F3 (St.4), F4 (St.3),F6 (St.1) } \\
\text { F3 (St.4), F4 (St.3),F6 (St.1) } \\
\text { F3 (St.4), F4 (St.3),F6 (St.1) } \\
\text { F3 (St.4), F4 (St.3),F6 (St.1) } \\
\text { F3 (St.4), F4 (St.3),F6 (St.1) } \\
\text { F3 (St.4), F4 (St.3),F6 (St.1) } \\
\text { F3 (St.4), F4 (St.3),F6 (St.1) } \\
\text { F3 (St.4), F4 (St.3),F6 (St.1) } \\
\text { F3 (St.4), F4 (St.3),F6 (St.1) } \\
\text { F3 (St.4), F4 (St.3)F6 (St.1) } \\
\text { F3 (St.4), F4 (St.3),F6 (St.1) }\end{array}$ \\
\hline C-1-1994 & 3123-35R3075-85 & - & - \\
\hline Mortar & $3135-45 R 3155-25$ & - & - \\
\hline Terrace/Road & $3135-50 \mathrm{R} 3125-35$ & - & 一 \\
\hline Gun Emp. & 3005-18R2975-95 & - & - \\
\hline Trench & 2945-060R3060-120 & - & - \\
\hline Well 1 & 3098R3134 & - & - \\
\hline
\end{tabular}


TABLE 1 (contd)

\begin{tabular}{llll}
\hline \hline Feature & $\begin{array}{l}\text { Provenience } \\
\text { E/N }\end{array}$ & Levels & Stratum \\
Well 2 & 3080R3076 & - & - \\
Well 3 & $3115 R 3000$ & - & - \\
Channel Race & 3105-270R2880-030 & - \\
Str. 5 & $3140-60$ R2985-002 & - & - \\
Str. 3 & $3165-180 R 2975-85$ & - & - \\
Str. 4 & $3185-215 R 2950-75$ & - & - \\
\hline
\end{tabular}

* Missing Levels 


\section{Stratum 1 (Field Designation F6)}

This is a regolithic clay, derived from eroded sandstone and shales of the Reklaw or Weches formations. It ranges in color from yellow $(2.5 \mathrm{Y} 7 / 6)$ to red $(2.5 \mathrm{YR} 5 / 8)$. Excavations proceeded only into the upper weathered contact. It is assumed to be horizontally continuous across the mapped sitc arca. Vertically, it extends from the ground surface in some areas to over $2 \mathrm{~m}$ below the ground surface. It was identified in units $\mathrm{N}-1, \mathrm{~N}-14,3163 \mathrm{R} 3135$, and 3115R3090. The uppermost boundary of this stratum is discontinuous, affected by the federal destruction of the Powder Mill and complex, years of raiding for construction materials, looting, farming, lumbering, and erosion. Generally, it is overlain by Stratum 3.

\section{Stratum 2 (Field Designation F5)}

This is a deposit of furnace slag and molten iron debris. The soil texture of the matrix is a sandy loam, black (10YR2/1); iron comprises ca. $80-90$ percent of the total

volume. Horizontally, it is discontinuous along the west wall of Feature A-1-1994, identified in units 3106R3069, 3107R3068, and 3107R3069. Vertically, it extends from a minimum of $10 \mathrm{~cm}$ to a maximum of $50 \mathrm{~cm}$ below the ground surface. It derived from a large furnace, which was dismantled, destroyed, and all remains of the hand-made brick chimney base removed.

\section{Stratum 3 (Field Designation F4)}

This stratum is a sandy loam, with a strong brown (7.5YR4/6) color. It contains many large, medium, and small fragments of hand-made brick. Horizontally, it is discontinuous across Feature A-1-1994, identified in units 3107R3090, 3109R3090, and 3115R3090. Vertically, it extends from a minimum of $10 \mathrm{~cm}$ to a maximum depth ranging from $37-60 \mathrm{~cm}$ below the ground surface. This stratum is derived from the 
landscaping associated with the construction of Feature A-1-1994, then its destruction, and subsequent scavenging and pothunting activities for the ensuing 130 years.

\section{Stratum 4 (Field Designation F3)}

This is the surficial stratum at the Marshall Powder Mill. It is a very dark gray (10YR3/1) to dark yellowish brown (10YR3/4) sandy loam. Horizontally, it is continuous across Feature A-1-1994, but discontinuous across the site as a whole. It was identified in units 3107R3090 $(0-11 \mathrm{~cm}), 3109 \mathrm{R} 3090(0-11 \mathrm{~cm}), 3115 \mathrm{R} 3090(0-10 \mathrm{~cm})$, 3106R3069, 3107R3068, and 3107R3069. Vertically, it extends from ground surface to a maximum excavated depth of $11 \mathrm{~cm}$. It is separated from the undcrlying Stratum 3 (Field designation of F4) by a diffuse boundary. Ferrous metal, hand-made brick, sandstone fragments, and charcoal are present.

\section{Features}

A-1-1994

This feature is a coursed ficldstone linear foundation which measures $37 \mathrm{~m}$ northsouth, with a $5 \mathrm{~m}$ long north wall, and a $10 \mathrm{~m}$ long south wall (Figure 5). Kettle fragments, molten iron, coal slag, and pig iron ingots were scattered across the surface of the feature. Three $1 \times 1 \mathrm{~m}$ excavation units $(3107 \mathrm{R} 3090,3109 \mathrm{R} 3090$, and 3115R3090) were emplaced across the northern end of the feature to determine the nature of the fill and the natural contact with the hillslope. A single 1 x 1 m unit (3113R3084) was emplaced over a hand-made brick concentration. Four 1 x $1 \mathrm{~m}$ units were emplaced over a large magnetic anomaly along the center of the west wall of the building, two of which (3106R3069 and 3107R3068) were eventually excavated. Finally, a $0.5 \mathrm{~m} \mathrm{x} 10 \mathrm{~m}$ trench (3105-3115R3056) was emplaced over the south wall to fully expose it.

Four strata were identified: Stratum 1, the underlying clay of the hillside; Stratum 2, furnacc slag and molten iron from the foundry; Stratum 3, a destruction fill contained 


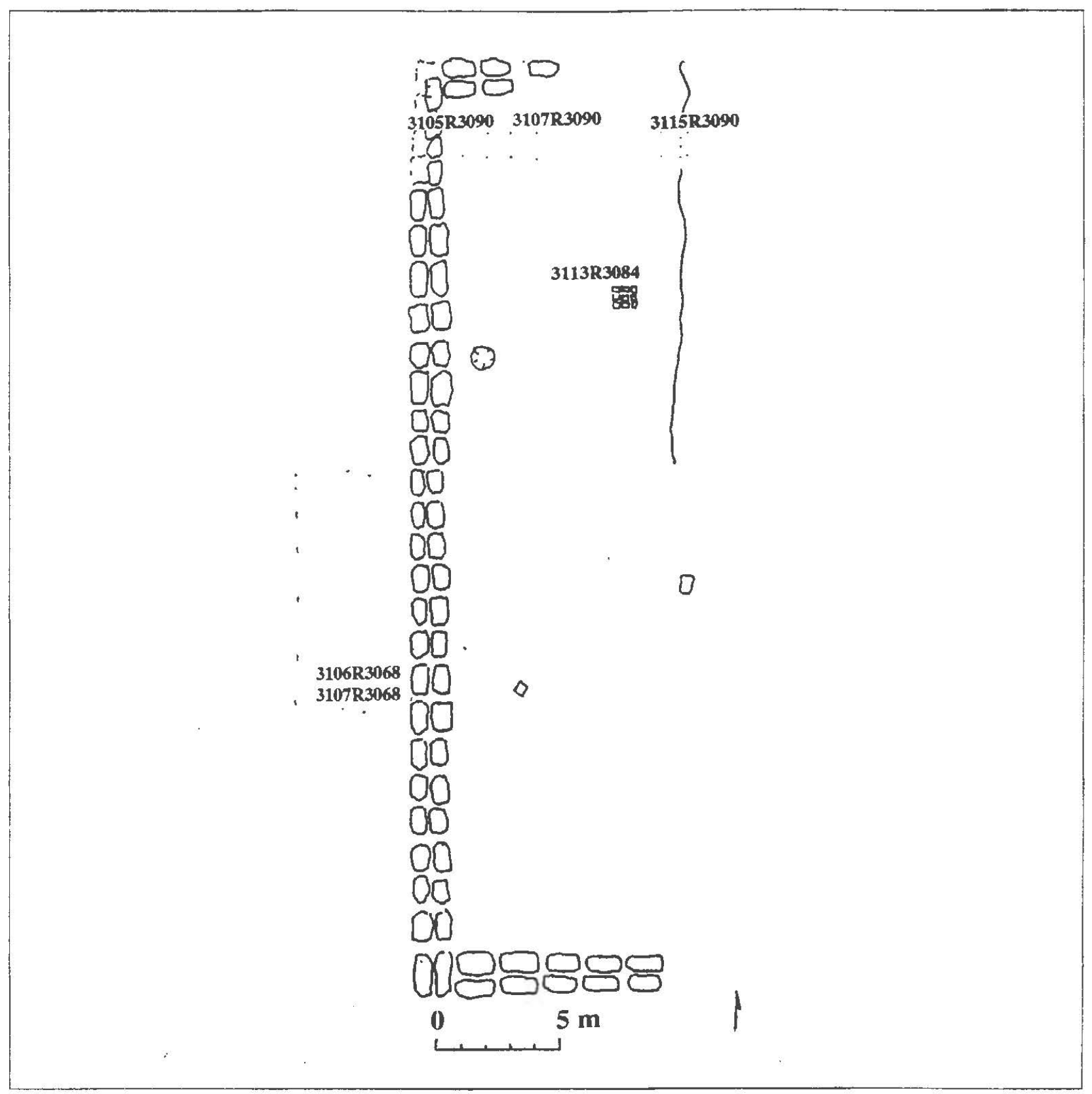

Figure 5. Excavation Units within Feature A-1-1994. 
burned lumber, handmade bricks, and mortar; and Stratum 4, a surficial soil formed since site abandonment. A total of 154 artifacts were recovered from the fill of this feature.

\section{A-2-1994}

This feature is a depression cut into the ridge, $15 \mathrm{~m}$ east of Feature A-1-1994, which measures $5 \times 6 \mathrm{~m}$. Metal soundings suggested that this may have been the location of a smelter. Burned brick fragments and pieces of kettles were noted on the ground surface. Two 1 x $1 \mathrm{~m}$ excavation units (3080R3122 and 3080R3123) were emplaced in the northeastern corner of the depression. The surface humus was removed from these units; however, heavy rains prevented any excavation within the fill. Two artifacts were collected from the surface, a fragment of molten iron slag which cooled, forming the cast of the original container (a small smelting kettle), and a smelting kettle rim sherd.

\section{B-1-1994}

This feature is an earthen depression within the gas pipeline ROW which appears to be a filled-in and partially re-excavated well. The feature measures $2 \times 3 \mathrm{~m}$. The surface humus was eroded from the area, and a $2 \mathrm{~m}$ grid was established (31713173R3133-3135) over the well. Work consisted of drawing a contour of the well hole (Figure 6).

\section{B-2-1994}

This feature is a mass of hand-made brick fragments, $4 \mathrm{~m}$ south of Feature B-11994, which was disturbed by backhoe activities along the gas pipeline ROW. It appears to have been a small building or structure foundation, which measures $4 \times 5 \mathrm{~m}$ (Figure 7). Surface humus was removed, but no grid was established or excavations begun during our investigations. 


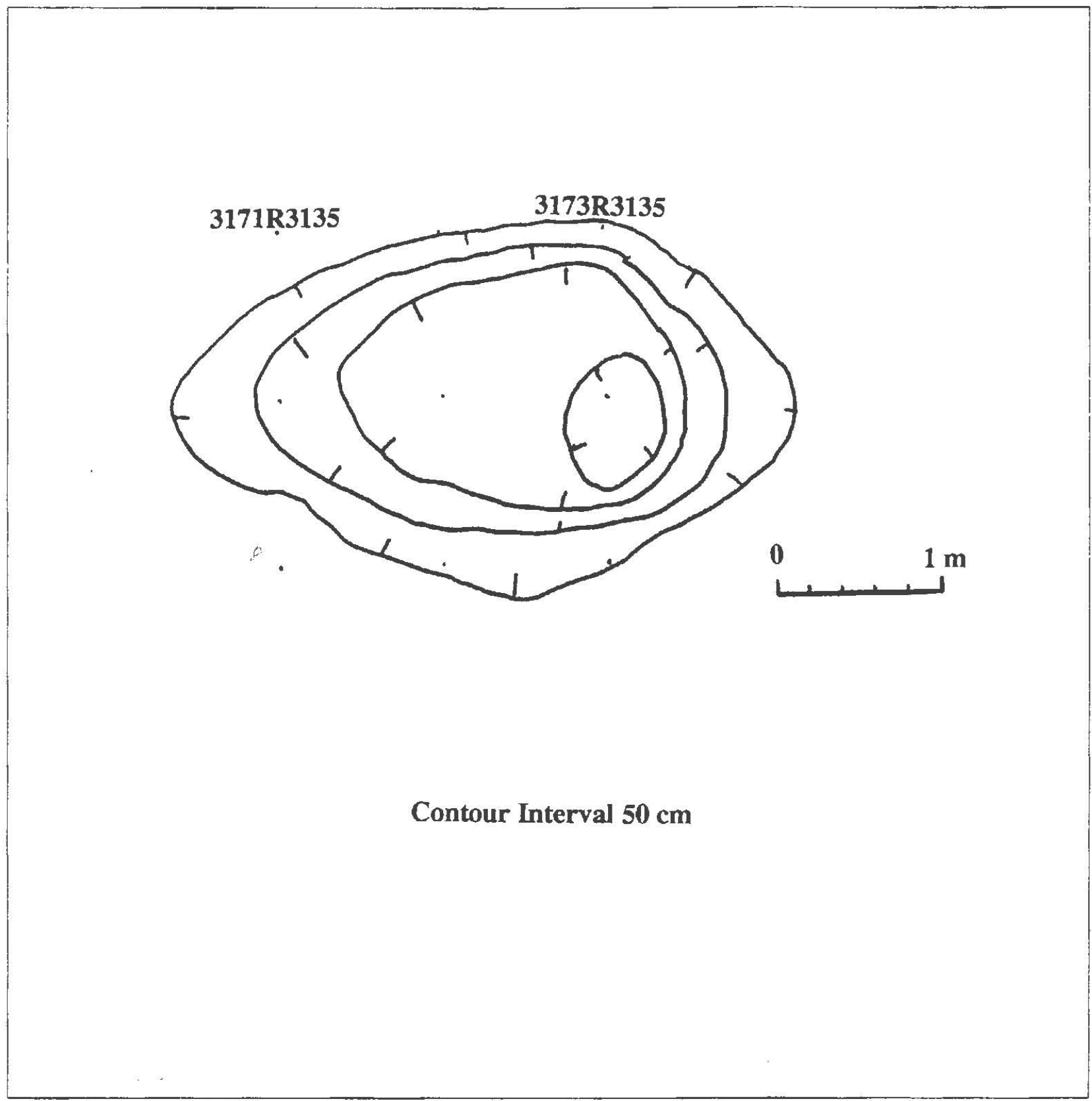

Figure 6. Contour map of Feature B-1-1994, a well. 


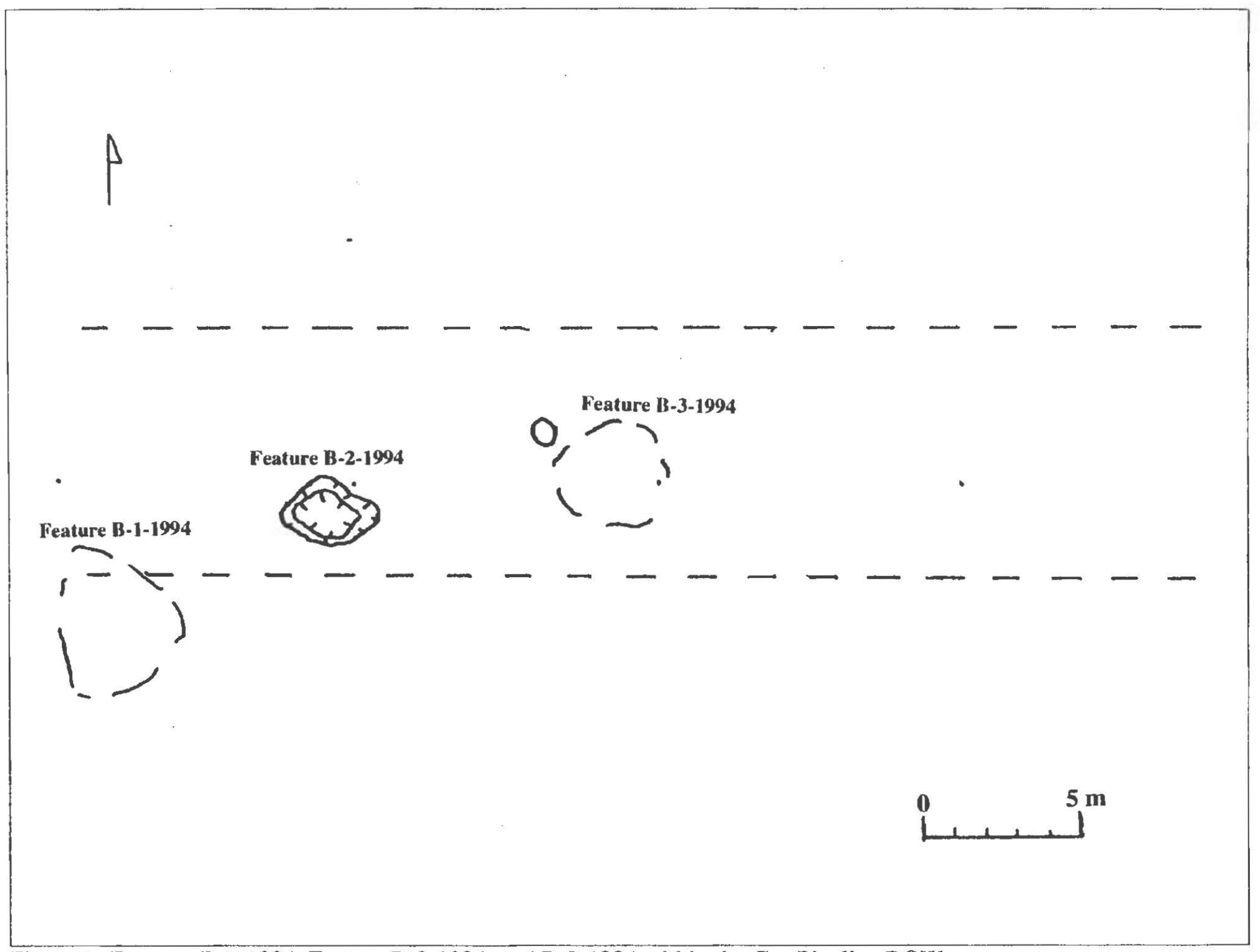

Figure 7. Features B-1-1994, Feature B-2-1994, and B-3-1994 within the Gas Pipeline ROW. 
B-3-1994

This feature is a mass of hand-made brick fragments and sandstone blocks, $6 \mathrm{~m}$ north of Feature B-1-1994, which was disturbed by backhoc activities along the gas pipeline ROW. It appears to have been a small building or structure foundation, which measures $3.5 \times 3.5 \mathrm{~m}$ (see Figure 7). Surface humus was removed, but no grid was established or excavation begun here.

B-4-1994

This feature was defined on the basis of metal detector scans, which were excavated by hand troweling to verify the soundings. It is located within the area from coordinates 3173-3195R3150-3175, suggesting a $20 \times 25$ m building or metal scatter (Figure 8). A total of 38 artifacts were recovered from this feature area.

\section{C-1-1994}

This feature is a depression cut into the lower slope of the hill, $10 \mathrm{~m}$ east of the southeast corner of Feature A-1-1994. The feature measures $6 \times 8 \mathrm{~m}$. It is adjacent to the arbitrary line dividing site Area A from site Area C. Many fragments of hand-made brick suggest wall and partition locations within the former building. The surface humus was removed from the area 3123-3125R3075-3085; however, heavy rains prevented any excavation or definition of wall lines.

\section{Material Culture Remains}

The material culture assemblages recovered from 1994 excavations at the Marshall Powder Mill consists of 341 items. This discounts hand-made brick fragments, rock fragments, and coal slag that were discarded in the field; their presence is noted in Table 2. The majority of the remains $(n=255)$ were recovered from Feature A-1-1994 (Fill $n=99$; Pier $n=21$; Slag $n=134$; and surface $n=3$ ), followed by: the metal seans in 


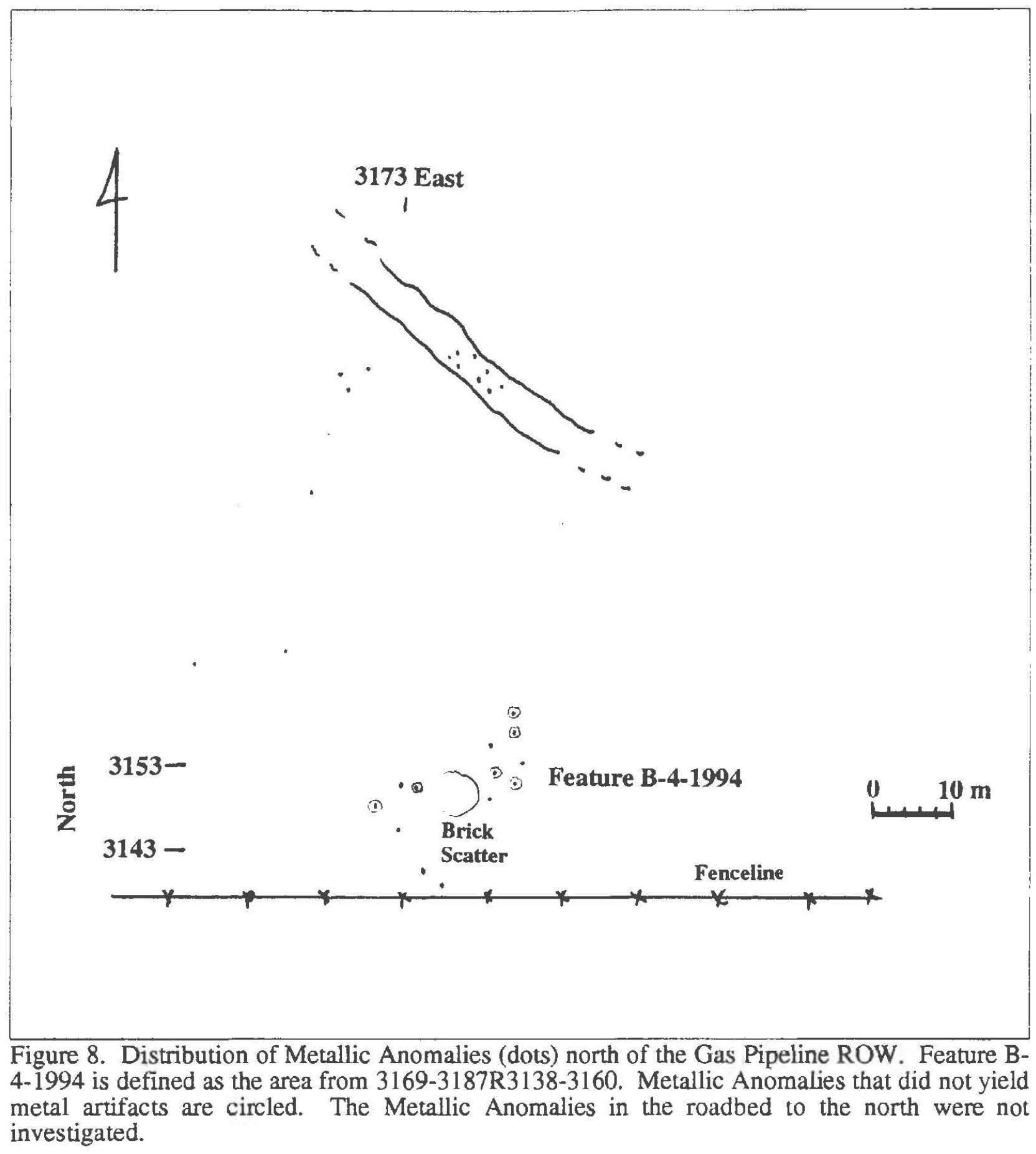


TABLE 2

Listing Of Artifacts Recovered From 1994 Investigations At The Marshall Powder Mill

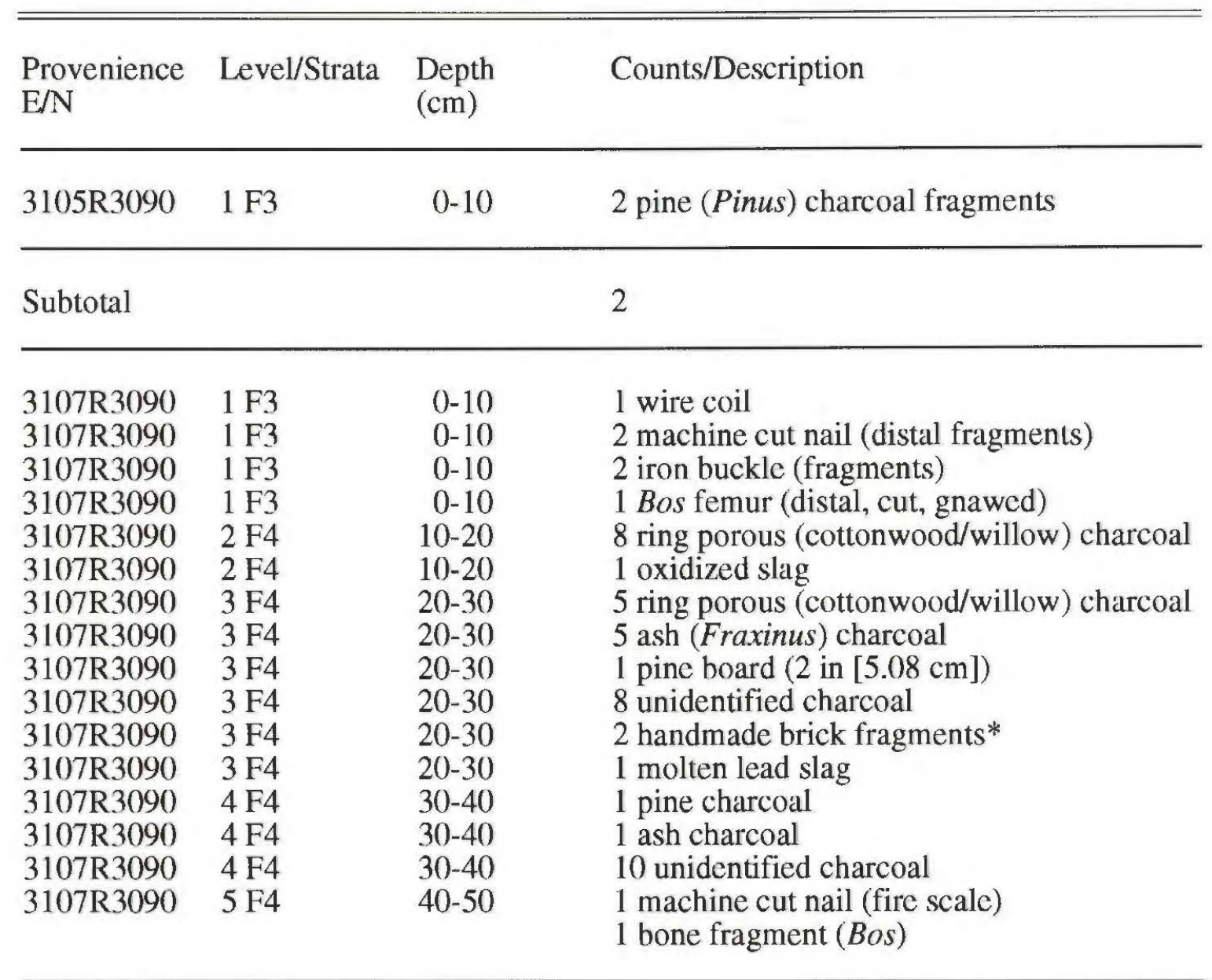

Subtotal

51

$\begin{array}{rrrr}3109 \mathrm{R} 3090 & 1 \mathrm{~F} 3 & 0-10 & 3 \text { unidentified charcoal } \\ 3109 \mathrm{R} 3090 & 2 \mathrm{~F} 4 & 10-20 & 8 \text { inidentified charcoal }\end{array}$

Subtotal

\begin{tabular}{|c|c|c|c|}
\hline 3106R3068 & $1 \mathrm{~F} 3$ & $0-10$ & 2 bottle glass (clear, green) \\
\hline 3106R3068 & $1 \mathrm{~F} 3$ & $0-10$ & $\begin{array}{l}2 \text { machine cut nails ( } 1 \text { prox. fire scale, } 1 \\
\text { whole roofing) }\end{array}$ \\
\hline 3106R3068 & $1 \mathrm{~F} 3$ & $0-10$ & 1 copper strip or buckle \\
\hline 3106R3068 & $1 \mathrm{~F} 3$ & $0-10$ & 1 iron handle \\
\hline $3106 \mathrm{R} 3068$ & $1 \mathrm{~F} 3$ & $0-10$ & 1 iron band \\
\hline $3106 \mathrm{R} 3068$ & $1 \mathrm{~F} 3$ & $0-10$ & 1 wire loop \\
\hline $3106 \mathrm{R} 3068$ & $1 \mathrm{~F} 3$ & $0-10$ & $6 \mathrm{rod} / \mathrm{wire}$ \\
\hline 3106R3068 & $1 \mathrm{~F} 3$ & $0-10$ & 1 mortar/handmade brick frag.* \\
\hline
\end{tabular}


TABLE 2 (contd)

\begin{tabular}{|c|c|c|c|}
\hline $\begin{array}{l}\text { Provenience } \\
\text { E/N }\end{array}$ & Level/Strata & $\begin{array}{l}\text { Depth } \\
(\mathrm{cm})\end{array}$ & Counts/Description \\
\hline 3106R3068 & $1 \mathrm{~F} 3$ & $0-10$ & 4 molten iron slag** \\
\hline 3106R3068 & $1 \mathrm{~F} 3$ & $0-10$ & 10 slag*** \\
\hline $3106 \mathrm{R} 3068$ & $2 \mathrm{~F} 5$ & $10-20$ & 1 kettle rim sherd \\
\hline $3106 \mathrm{R} 3068$ & $2 \mathrm{~F} 5$ & $10-20$ & 1 flat latch with raised groove and flange \\
\hline 3106R3068 & $2 \mathrm{~F} 5$ & $10-20$ & 1 melted bushing? \\
\hline $3106 \mathrm{R} 3068$ & $2 \mathrm{~F} 5$ & $10-20$ & $3 \mathrm{rod} / \mathrm{wire}$ \\
\hline 3106R3068 & $2 \mathrm{~F} 5$ & $10-20$ & $\begin{array}{l}3 \text { molten iron**(one with fibers from } \\
\text { wooden casing?) }\end{array}$ \\
\hline 3106R3068 & $2 \mathrm{~F} 5$ & $10-20$ & 11 slag*** \\
\hline 3106R3068 & $3 \mathrm{~F} 5$ & $20-30$ & 1 kettle sherd \\
\hline $3106 \mathrm{R} 3068$ & 3 F5 & $20-30$ & 1 flange \\
\hline $3106 \mathrm{R} 3068$ & 3 F5 & $20-30$ & $\begin{array}{l}5 \text { machine cut nails (one stud framing, wood } \\
\text { on metal indicated by flattened tip, and with } \\
\text { fire scale) }\end{array}$ \\
\hline 3106R3068 & $3 \mathrm{~F} 5$ & $20-30$ & 2 inner sheaths cannon balls \\
\hline 3106R3068 & $3 \mathrm{~F} 5$ & $20-30$ & 2 tubes \\
\hline 3106R3068 & $3 \mathrm{~F} 5$ & $20-30$ & 1 fire brick frag.* \\
\hline 3106R3068 & $3 \mathrm{~F} 5$ & $20-30$ & $3 \mathrm{rod} /$ wire \\
\hline $3106 \mathrm{R} 3068$ & 3 F5 & $20-30$ & 3 molten iron slag** \\
\hline $3106 \mathrm{R} 3068$ & $3 \mathrm{~F} 5$ & $20-30$ & 7 slag*** \\
\hline $3106 \mathrm{R} 3068$ & 4 F5 & $30-40$ & 1 brass/copper buttplate frag. \\
\hline 3106R3068 & 4 F5 & $30-40$ & $\begin{array}{l}1 \text { brass/copper buttplate reinforcement (with } \\
\text { clinch mark from dismantling) }\end{array}$ \\
\hline 3106R3068 & 4 F5 & $30-40$ & 1 fluted iron machine/stove part \\
\hline 3106R3068 & 4 F5 & $30-40$ & $\begin{array}{l}4 \text { machine cut nails (one firescale indicating } \\
1.0 \text { in }[2.54 \mathrm{~cm}] \text { siding board, one clinched) }\end{array}$ \\
\hline $3106 \mathrm{R} 3068$ & 4 F5 & $30-40$ & 1 horseshoe nail \\
\hline 3106R3068 & 4 F5 & $30-40$ & $5 \mathrm{rod} / \mathrm{wire}$ \\
\hline 3106R3068 & $4 \mathrm{~F} 5$ & $30-40$ & 6 molten iron slag** \\
\hline 3106R3068 & 4 F5 & $30-40$ & $8 \operatorname{slag}^{* * *}$ \\
\hline
\end{tabular}

Subtotal

100

$\begin{array}{llr}\text { 3107R3068 } & \text { 1 F3 } & 0-10 \\ \text { 3107R3068 } & \text { 1 F3 } & 0-10 \\ \text { 3107R3068 } & \text { 1 F3 } & 0-10 \\ & & \\ & & 0-10 \\ \text { 3107R3068 } & \text { 1 F3 } & 10-20 \\ \text { 3107R3068 } & \text { 2 F5 } & 10-20 \\ \text { 3107R3068 } & \text { 2 F5 } & 10-20 \\ \text { 3107R3068 } & \text { 2 F5 } & \end{array}$

1 green ABM glass (post 1919)

1 pine board (1in [2.54 cm])

4 molten iron** (one gives kettle impression ca. $2 \mathrm{~m}[6.56 \mathrm{ft}]$ diameter, see sherd from pothunter pile Feature A-2-1994) 3 slag***

2 ABM glass (green, clear; post 1919)

1 fluted iron stove part 1 stove/machine part (applique lettering, lower portion of a block $S$ from the word Marshall) 
TABLE 2 (contd)

\begin{tabular}{llll}
\hline \hline $\begin{array}{l}\text { Provenience } \\
\text { E/N }\end{array}$ & Level/Stratal & $\begin{array}{l}\text { Depth } \\
\text { (cm) }\end{array}$ & Counts/Description \\
\hline 3107R3068 & 2 F5 & $10-20$ & 1 molten copper \\
3107R3068 & 2 F5 & $10-20$ & 7 molten iron**(one dropped in watcr) \\
$3107 R 3068$ & 2 F5 & $10-20$ & 6 slag*** \\
3107R3068 & 3 F5 & $20-30$ & 1 iron lever \\
3107R3068 & 3 F5 & $20-30$ & 1 unidentified machine part \\
3107R3068 & 3 F5 & $20-30$ & 1 rod/wire \\
3107R3068 & 3 F5 & $20-30$ & 3 slag*** \\
3107R3068 & 4 F5 & $30-40$ & 1 handmade brick frag. \\
3107R3068 & 4 F5 & $40-50$ & sterile? \\
\hline
\end{tabular}

Subtotal

$\begin{array}{lll}\text { 3113R3084 } & \text { 1F3 } & 0-10 \\ \text { 3113R3084 } & \text { 1 F3 } & 0-10 \\ \text { 3113R3084 } & \text { 1 F3 } & 0-10 \\ \text { 3113R3084 } & \text { 1 F3 } & 0-10 \\ \text { 3113R3084 } & \text { 1 F3 } & 0-10 \\ \text { 3113R3084 } & \text { 1 F3 } & 0-10 \\ & & \\ \text { 3113R3084 } & \text { 2 F4 } & 10-20 \\ \text { 3113R3084 } & \text { 3 F4 } & 20-30 \\ \text { 3113R3084 } & \text { 4 F4 } & 30-35 \\ \text { 3113R3084 } & \text { 5 F6 } & 35-40 \\ 3113 R 3084 & 5 \mathrm{~F} 6 & 35-40 \\ \text { 3113R3084 } & 5 \mathrm{~F} 6 & 35-40 \\ \text { 3113R3084 } & 5 \mathrm{~F} 6 & 35-40\end{array}$

\section{4}

handmade brick fragments****

2 large machine cut framing spikes

9 machine cut framing nails

1.22 caliber rifle bullet

2 iron wedges

2 coal slag

handmade brick fragments****

handmade brick fragments****

handmade brick fragments****

1 pine board $(1$ in $[2.54 \mathrm{~cm}])$

1 ash limb (ax cut marks)

1 handmade brick*

2 machine cut nails (one whole roofing, firescale)
Subtotal

$\begin{array}{llr} & & \\ 3115 R 3090 & \text { 1 F3 } & 0-10 \\ \text { 3115R3090 } & \text { 1 F3 } & 0-10 \\ \text { 3115R3090 } & \text { 1 F3 } & 0-10 \\ \text { 3115R3090 } & \text { 1 F3 } & 0-10 \\ \text { 3115R3090 } & \text { 1 F3 } & 0-10 \\ \text { 3115R3090 } & \text { 2 F4 } & 10-20\end{array}$

21

2 pine board**** (1 in $[2.54 \mathrm{~cm}])$

1 pine limb (with bark?)****

27 unidentified charcoal****

3 machine cut nails (two roofing, one siding)

1 lag bolt/hook (light duty)

1 large machine cut spike (firescale) 
TABLE 2 (contd)

\begin{tabular}{|c|c|c|c|}
\hline $\begin{array}{l}\text { Provenience } \\
\text { E/N }\end{array}$ & Lcvel/Strata & $\begin{array}{l}\text { Depth } \\
\text { (cm) }\end{array}$ & Counts/Description \\
\hline
\end{tabular}

Metal Scan Trowel Tests Feature B-4-1994

\begin{tabular}{|c|c|c|c|}
\hline 3177R3150 & $1 \mathrm{~F} 3, \mathrm{~F} 4, \mathrm{~F} 6$ & $0-20$ & 1 ceramic sherd \\
\hline 3177R3150 & $1 \mathrm{~F} 3, \mathrm{~F} 4, \mathrm{~F} 6$ & $0-20$ & 1 bottle glass sherd \\
\hline 3177R3150 & $1 \mathrm{~F} 3, \mathrm{~F} 4, \mathrm{~F} 6$ & $0-20$ & 1 machine cut nail \\
\hline $3175.5 R 3153$ & $1 \mathrm{~F} 3, \mathrm{~F} 4, \mathrm{~F} 6$ & $0-20$ & 1 ceramic sherd \\
\hline $3175.5 R 3153$ & $1 \mathrm{~F} 3, \mathrm{~F} 4, \mathrm{~F} 6$ & $0-20$ & 1 machine cut nail \\
\hline 3175.2R3150.7 & $1 \mathrm{~F} 3, \mathrm{~F} 4, \mathrm{~F} 6$ & $0-15$ & 1 aqua bottle glass \\
\hline $3175.2 \mathrm{R} 3150.7$ & $1 \mathrm{~F} 3, \mathrm{~F} 4, \mathrm{~F} 6$ & $0-15$ & 1 machine cut nail \\
\hline $3175.2 \mathrm{R} 3150.7$ & $1 \mathrm{~F} 3, \mathrm{~F} 4, \mathrm{~F} 6$ & $0-15$ & 1 ceramic sherd \\
\hline 3174.2R 3152.8 & $1 \mathrm{~F} 3, \mathrm{~F} 4, \mathrm{~F} 6$ & $0-15$ & 1 machine cut nail \\
\hline 3174.2R3152.8 & $1 \mathrm{~F} 3, \mathrm{~F} 4, \mathrm{~F} 6$ & $0-15$ & 2 ceramic sherds \\
\hline 3173R3157 & $1 \mathrm{~F} 3, \mathrm{~F} 4, \mathrm{~F} 6$ & $0-15$ & 1 machine cut spike \\
\hline 3173R3157 & $1 \mathrm{~F} 3, \mathrm{~F} 4, \mathrm{~F} 6$ & $0-15$ & 1 machine cut nail \\
\hline $3169.5 \mathrm{R} 3161$ & $1 \mathrm{~F} 3, \mathrm{~F} 4, \mathrm{~F} 6$ & $0-15$ & 0 \\
\hline 3173.3R3162 & $1 \mathrm{~F} 3, \mathrm{~F} 4, \mathrm{~F} 6$ & $0-20$ & 1 ceramic sherd \\
\hline 3173.3R3162 & $1 \mathrm{~F} 3, \mathrm{~F} 4, \mathrm{~F} 6$ & $0-20$ & 1 bottle glass sherd \\
\hline 3173.3R3162 & $1 \mathrm{~F} 3, \mathrm{~F} 4, \mathrm{~F} 6$ & $0-20$ & 2 machine cut nails \\
\hline 3173.5R3163 & $1 \mathrm{~F} 3, \mathrm{~F} 4, \mathrm{~F} 6$ & $0-15$ & 2 glass sherds \\
\hline 3183.8R3161 & $1 \mathrm{~F} 3, \mathrm{~F} 4, \mathrm{~F} 6$ & $0-25$ & 1 ceramic sherd \\
\hline 3183.8R3161 & $1 \mathrm{~F} 3, \mathrm{~F} 4, \mathrm{~F} 6$ & $0-25$ & 1 bottle glass sherd \\
\hline 3183.8R3161 & $1 \mathrm{~F} 3, \mathrm{~F} 4, \mathrm{~F} 6$ & $0-25$ & 1 machine cut nail \\
\hline 3186R3163 & $1 \mathrm{~F} 3, \mathrm{~F} 4, \mathrm{~F} 6$ & $0-25$ & 0 \\
\hline 3184R3164.8 & $1 \mathrm{~F} 3, \mathrm{~F} 4, \mathrm{~F} 6$ & $0-25$ & 1 ceramic sherd \\
\hline 3184R3168 & $1 \mathrm{~F} 3, \mathrm{~F} 4, \mathrm{~F} 6$ & $0-15$ & 1 machine cut nail \\
\hline 3184R3161 & $1 \mathrm{~F} 3, \mathrm{~F} 4, \mathrm{~F} 6$ & $0-15$ & 1 Ogallala quartzite flake \\
\hline $3184 \mathrm{R} 3161$ & $1 \mathrm{~F} 3, \mathrm{~F} 4, \mathrm{~F} 6$ & $0-15$ & 4 machine cut nails \\
\hline 3184R3161 & $1 \mathrm{~F} 3, \mathrm{~F} 4, \mathrm{~F} 6$ & $0-15$ & 1 clear bottle glass \\
\hline 3184R3161 & $1 \mathrm{~F} 3, \mathrm{~F} 4, \mathrm{~F} 6$ & $0-15$ & 5 ceramic sherds \\
\hline $3187.5 \mathrm{R} 3165$ & $1 \mathrm{~F} 3, \mathrm{~F} 4, \mathrm{~F} 6$ & $0-15$ & 1 ceramic sherd \\
\hline $3187.5 \mathrm{R} 3165$ & $1 \mathrm{~F} 3, \mathrm{~F} 4, \mathrm{~F} 6$ & $0-15$ & 1 bottle glass sherd \\
\hline $3187.5 \mathrm{R} 3165$ & $1 \mathrm{~F} 3, \mathrm{~F} 4, \mathrm{~F} 6$ & $0-15$ & 1 machine cut nail \\
\hline 3193R3165.3 & $1 \mathrm{~F} 4, \mathrm{~F} 6$ & $0-5$ & 1 machine cut nail \\
\hline 7R3169.2 & $1 \mathrm{~F} 4, \mathrm{~F} 6$ & $0-16$ & 1 ceramic sherd \\
\hline 3187R3173 & 1 F4,F6 & $0-17$ & 1 mussel shell? \\
\hline
\end{tabular}

Subtotal

24

3107.5R3074 Surface

1 iron stove/valve cover plate (marked 3 SPINDEN) 
TABLE 2 (contd)

\begin{tabular}{lll}
\hline \hline $\begin{array}{l}\text { Provenience Level/Strata } \\
\text { E/N }\end{array}$ & $\begin{array}{c}\text { Depth } \\
(\mathrm{cm})\end{array}$ & Counts/Description \\
\hline Feature A-1-1994 & 0 & 2 iron moldgates-cannon \\
\hline Subtotal & 2 & $\begin{array}{l}1 \text { molten iron slag (indicating a small kettle, } \\
24 \text { in [60.96 cm] diameter, 9.5 in [24.13 cm] } \\
\text { high, with two sets of venting flutes at the } \\
\text { basc) } \\
1 \text { kettle rim (cst. 1-2 m, with curved or } \\
\text { spouted rim) }\end{array}$ \\
Feature A-2-1994 & 0 &
\end{tabular}

Subtotal

2

\begin{tabular}{|c|c|c|}
\hline $\begin{array}{l}\text { Raceway Lag } \\
\text { relief, }\end{array}$ & 0 & $\begin{array}{l}5 \text { ironstone s herds }(1860-1910 \text {; one edge- } \\
\text { scalloped plate, one sugar bowl lid, one } \\
\text { chamber/tureen) }\end{array}$ \\
\hline $\begin{array}{l}\text { Raceway Lag } \\
1860-\end{array}$ & 0 & $\begin{array}{l}2 \text { porcelain sherds (one flow blue saucer } \\
1890 \text {, one tea cup) }\end{array}$ \\
\hline Raceway Lag & 0 & $\begin{array}{l}3 \text { stoneware sherds ( } 1850-1870 \text {; two jug/jar } \\
\text { bases) }\end{array}$ \\
\hline Raceway Lag & 0 & 1 tile (matches fire brick from forge) \\
\hline Raceway Lag & 0 & $\begin{array}{l}1 \text { prehistoric sherd (Caddoan, grog } \\
\text { tempered, incised) } \\
1 \text { sidenotched chert dart (Ellis-like) }\end{array}$ \\
\hline Subtotal & & 12 \\
\hline \multicolumn{3}{|l|}{$\overline{\text { Area } \mathrm{G}}$} \\
\hline HorseTrack & 0 & $\begin{array}{l}6 \text { Caddoan sherds ( one grog tempered broad } \\
\text { line incised, one grog and bone tempered, } \\
\text { curvilinear incised, and one white filmed } \\
\text { with grog temper) }\end{array}$ \\
\hline HorseTrack & 0 & $\begin{array}{l}2 \text { chert flakes (tan, gray) } \\
1 \text { stemmed chert dart point base } \\
1 \text { novaculite flake } \\
5 \text { chert flakes } \\
3 \text { quartzite flakes }\end{array}$ \\
\hline
\end{tabular}

Subtotal 
TABLE 2 (contd)

\begin{tabular}{lll}
\hline \hline $\begin{array}{l}\text { Provenience Level/Strata } \\
\text { E/N }\end{array}$ & $\begin{array}{l}\text { Depth } \\
(\mathrm{cm})\end{array}$ & Counts/Description \\
\hline $\begin{array}{l}\text { Loop 390 ROW } \\
\text { Loop 390 ROW }\end{array}$ & 0 & $\begin{array}{l}\text { 1 ABM returnable soda bottle (1919-1950) } \\
\text { Loop 390 ROW }\end{array}$ \\
\hline $\begin{array}{l}\text { Subtotal transfer print (1860-1910) } \\
\text { So ironstone/whiteware }(1860-1910)\end{array}$ \\
\hline Total & 0 & 12 \\
\hline
\end{tabular}

* sampled by examination of brick fragments, remainder discarded

** sampled by examination of all iron, remainder discarded

*** sampled by examination of all slag (predominantly coal), remainder discarded

**** discarded 
Feature B-4-1994 ( $n=41)$, surface collections in the Horse Track of Area $G(n=18)$; collections from the gravel lag deposits in the channel race $(n=13)$, and surface collections along the Loop 390 ROW $(n=12)$.

\section{Feature A-1-1994 Material Culture}

North Trench

The material culture assemblagc rccovered from the northern trench $(3105-$ 3115R3090) through Feature A-1-1994 consists of ash, willow, and pine charcoal ( $n=79)$, carbonized pine boards $(n=3)$, machine cut nails $(n=6)$, a large machine cut spike, coal slag, lead slag, two hand-made brick fragments, two iron buckles, a wire coil, two bone fragments, and a light duty lag bolt hook. The bones are from beef cuts. The charcoal is from species that were used to make gunpowder (willow and ash), and for fuel and lumber (pine). The machine cut nails exhibit fire scale and breakage patterns indicative of 2 inch board siding, and post or timber framing.

The architectural assemblage indicates that a one or two story frame structure with a hand-made brick west wall once stood here. The burning patterns suggest that it was burned in place, and the best hand-made bricks then salvaged.

\section{Hand-made Brick Pier}

The material culture assemblage from the $1 \times 1 \mathrm{~m}$ unit (3113R3084) over this brick concentration revealed five courses of bricks which formed a pyramidal pier. This confirms that a wooden-floored story stood over the northern end of Feature A-1-1994. A single handmade brick fragment was collected. Architectural items dominated the assemblage, and included two machine cut spikes and nine machine cut nails. A carbonized ash limb exhibited axe marks. A burned pine board measured 1 inch thick. A single .22 rifle bullet represents twentieth century activities on the site. 
Slag Deposit

The material culture assemblage from the two $1 \times 1 \mathrm{~m}$ units along the west wall and the magnetic anomaly is dominated by coal and metal slag (only representative samples of color and texture variability were made), tools and machine parts, and fragments of firearms and munitions. The assemblage is dominated by iron slag $(n=69)$, iron rods $(n=18)$ used in welding, machine cut nails $(n=11)$, and coal slag $(n=6)$. One fragment of coal slag formed the cast of the kettle which held it, estimated to be nearly 2 $\mathrm{m}$ in diameter. Other architecture remains included two hand-made brick fragments, a fire-brick fragment, and a carbonized pine board measuring 1 inch thick. Other tools or machine parts included two kettle rims and a kettle flange, a valve cover marked 3 SPINDEN, two 6 inch mold gates (cannon?), an iron handle, an iron band, a wire loop, a lever, a latch, a bushing, three stove parts (one door with applique $S$, possibly

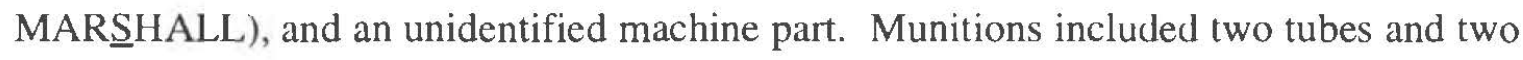
spheres that appear to be cannonball parts. Two brass rifle butt plates represent recast firearms. Other items included a horseshoe nail, a copper strip, and molten copper.

Feature A-2-1994

Only two notable surface finds were collected. These are a molten slag lump and a kcttle rim. The molten slag forms the cast of the container vessel, a small kettle $(0.6 \mathrm{~m}$ in diameter and $25 \mathrm{~cm}$ high) with two sets of venting flutes at the base. The kettle rim sherd is from a vessel estimated to be 1-2 $\mathrm{m}$ in diameter with a curved or spouted rim.

Feature B-4-1994

A total of 38 items were recovered from this feature area. The artifact assemblage was dominated by ceramic $(n=15)$ sherds (two blue transfer print [1860-1880] and one annular [1850-1880] whitewares, one hand-painted ironstone [1840-1860], and eight ironstone/whiteware [1860-1910]), machinc cut nails $(n=15)$, a large machine cut framing 
spike, and eight bottle glass sherds. Also included are a mussel shell and a quartzite flake.

Area A, Lag Deposits from the Channel Race

Diagnostic ceramic shcrds and prehistoric artifacts were collected from the channel of the stream in Area A below the artificial channel race. Eleven historic and two prchistoric items were recovered. The historic artifacts include three ironstone (one edge-scalloped plate, one sugar bowl lid, one chamber pot or tureen [1860-1910]) and two porcelain (a flow blue saucer dated ca. 1890 and one tea cup) sherds; three stoneware (1850-1870) sherds [two jug/jar bases]; and a fire brick tile. The prehistoric items include a grog-tempered, incised sherd and a side-notched (Ellis-like) chert dart point.

\section{Area G, Horse Track Surface}

Only prehistoric items were recovered from this area. They include six ceramic (one grog-tempered, broad line incised; one grog and bone-tempered, curvilinear incised; and onc grog-tempered with white film) sherds; seven chert flakes, one novaculite flake, three quartzite flakes, and one stemmed dart (chert) point base.

Loop 390, Surface

The artifact assemblage from this area consisted of 11 ceramic sherds and one bottle glass fragment. The bottle sherd was from an automated bottling machine (19191950) returnable soda bottle. The ceramics consisted of one blue transfer print (1860$1910)$ and 10 ironstone/whiteware (1860-1910) sherds.

\section{CONCLUSIONS}

The history of the Civil War in Texas generates public interest, yet the presence of the gunpowder mill at Marshall and its history are not generally known. Public education 
is essential to alleviate potential destruction of cultural resources within the county generally, and the Marshall Powder Mill, specifically. This project provided public awareness of the need to preserve archaeological resources, training for elementary and college students, and demonstrated that extensive and well preserved features and deposits remain at the Marshall Powder Mill. These remains provide clues to the original function of various buildings, and identify specialized metallurgy areas.

The Texas Highway Department apparently buried the foundations of the three buildings and the pond they uncovered under fill. These remains are still protected within the Loop 390 corridor. The site of the powder mill itself, the powder magazine shown on the undated map, and another large pond complex lie to the south, has not been addressed to date. The Marshall Powder Mill, if adequately protected, could yield significant archaeological and historical information far into the future.

\section{ACKNOWLEDGEMENTS}

This project reached completion through the aid of many individuals. Members of the Dallas County, East Texas, Northeast Texas, and Tarrant County archeological societies offered labor and support throughout the project. The landowner, Mr. Olan Phillips, granted access to the site. The Texas Historical Commission's Department of Antiquities Protection and Office of the State Archeologist staffs offercd guidance and consultation throughout. Kevin Davis, of Davis and McGill, Waxahachie, Texas, kindly completed the topographic survey, grid extension, and established permanent datums across the site. Bobby Ware, of the Henderson Brick Co., Marshall, Texas, provided ficld information on brick types. Eugene Foster, Espey, Huston \& Associates, Inc. (Austin, Texas), examined the foundation remains and channel race, and provided information on water-powered mills in East Texas.

Members of the Northeast Texas Archeological Society (NETAS) that provided constant support and labor include Patty Haskins, John Goldman, John (Mackey) 
McIntosh, Thomas Goldman, and Mary Cay Jones. Many other NETAS members and interested citizens contributed to the effort. Finally, this report is dedicated to the late Larry Fant, President of NETAS, who untimely passed away during the course of the project. 
Luke, C. J.

1978 The Marshall Powder Mill. Publications in Archaeology, Report 11. State Department of Highways and Public Transportation, Highway Design Division, Austin.

National Archives

n.d. Records of the Office of the Chief Engineer, Headquarters Map File. Record Group 77, Subgroup B. Map Z 52-5.

Nichols, J. L.

1964 The Confederate Quartermaster in the Trans-Mississippi. University of Texas Press, Austin.

Parks, J. H.

1954 General E. Kirby Smith C.S.A. Louisiana State University Press, Baton Rouge.

Roney, J., III

1962 Marshall, Texas, 1860-1865. Unpublished M. A. Thesis, Baylor University.

Skinner, S. A.

n.d. Personal notes and logs from investigation of $41 \mathrm{HS} 17$ on March 24, 1971 for Department of Anthropology, Southern Methodist University, at request of Curtis Tunnell, State Archeologist.

Strong, D. E. and M. Hilton

1992 Remote Sensing Survey of Area G at Caesarea. Paper for the Annual Meeting of the American Schools of Oriental Research.

Texas and Pacific Railway

1947 From Ox-Teams to Eagles: A History of the Texas and Pacific Railway. (Publisher Unknown). 
Weir, F. A.

1973 The Marshall Powder Mill: A Preliminary Report. Report 3. Texas Department of Highways and Public Transportation, Highway Design Division, Austin.

Whaley, J.

1919 Marshall and Harrison County during the Civil War and the Reconstruction Period. Sketches drawn from Marshall and Vicinity, Past and Present by the Students of the Marshall High School. Price's Print, Marshall, Texas. 